NBER WORKING PAPER SERIES

\title{
THE IMPACT OF CARTELIZATION, MONEY, AND PRODUCTIVITY SHOCKS ON THE INTERNATIONAL GREAT DEPRESSION
}

\author{
Harold L. Cole \\ Lee E. Ohanian \\ Working Paper 18823 \\ http://www.nber.org/papers/w18823
NATIONAL BUREAU OF ECONOMIC RESEARCH
1050 Massachusetts Avenue
Cambridge, MA 02138
February 2013

There have been too many people who contributed to this paper to thank them all. However, we particularly thank Jesus Fernandez-Villaverde, Ellen McGrattan and Edward Prescott. We also thank Ron Leung and Giang Ho for exceptional research assistance. The views expressed herein are those of the authors and do not necessarily reflect the views of the National Bureau of Economic Research.

NBER working papers are circulated for discussion and comment purposes. They have not been peerreviewed or been subject to the review by the NBER Board of Directors that accompanies official NBER publications.

(C) 2013 by Harold L. Cole and Lee E. Ohanian. All rights reserved. Short sections of text, not to exceed two paragraphs, may be quoted without explicit permission provided that full credit, including (C) notice, is given to the source. 
The Impact of Cartelization, Money, and Productivity Shocks on the International Great Depression Harold L. Cole and Lee E. Ohanian

NBER Working Paper No. 18823

February 2013

JEL No. F1,N12

\begin{abstract}
$\underline{\text { ABSTRACT }}$
This study exploits panel data from 18 countries to assess the contributions of cartelization policies, monetary shocks, and productivity shocks on macroeconomic activity during the Great Depression. To construct a parsimonious and common model framework, we use the fact that many cartel policies are observationally equivalent to a country-specific labor tax wedge. We estimate a monetary DSGE model with cartel wedges along with productivity and monetary shocks. Our main finding is that cartel policy shocks account for the bulk of the Depression in the countries that adopted significant cartel policies, including the large depressions in the U.S., Germany, Italy, and Australia, and that the estimated cartel policy shocks plausibly coincide with the actual evolution of policies in these countries. In contrast, cartel policy shocks in the countries that did not significantly change policies were small and account for little of their Depressions.
\end{abstract}

\author{
Harold L. Cole \\ Economics Department \\ University of Pennsylvania \\ 3718 Locust Walk \\ 160 McNeil Building \\ Philadelphia, PA 19104 \\ and NBER \\ colehl@sas.upenn.edu \\ Lee E. Ohanian \\ 8283 Bunche Hall \\ UCLA, Department of Economics \\ Box 951477 \\ Los Angeles, CA 90095 \\ and NBER \\ ohanian@econ.ucla.edu
}




\section{Introduction}

Cole and Ohanian (1999, 2004) and Ohanian (2009) present theory and evidence that cartelization policies that distort incentives and reduce competition in product and labor markets contributed significantly to the U.S. Great Depression. This paper analyzes how much cartelization policies contributed to the world depression of the 1930s, as other countries, including Italy under Mussolini, and Germany under Hitler, expanded cartel policies significantly during the 1930s.

We exploit the fact that there are large cross-country differences in the severity of these policies during the Depression. Specifically, while the U.S., Germany, and Italy substantially expanded cartel policies in the 1930s relative to the 1920s, other countries, such as the United Kingdom and Canada did not. These large cross-country policy differences facilitate estimating their contribution to the world depression of the 1930s. At the same time, we also estimate the contribution of two other shocks, monetary shocks and productivity shocks. This allows us to assess the roles played by these three shocks in impacting output, consumption, investment, employment and other variables during the Depression.

We construct a macroeconomic panel dataset for 18 countries. Nearly all countries have consistent time series of real GNP, the GNP deflator, the money supply, real consumption, and real investment. We focus the analysis on the seven countries that also have consistent aggregate employment and capital data: Australia, Canada, France, Germany, Italy, U.S. and the U.K. We use the other 11 countries to assess the robustness of the findings.

Our main finding is that the estimated cartel shocks are quantitatively very important for the cartelized countries, as they account for more than 80 percent of employment change in the U.S., Germany, Italy, and Australia. Moreover, the size of the estimated cartel shocks, and their evolution over time, are in line with the evolution of actual cartel policies across these countries. Specifically, the estimated cartel shocks are large and negative in the countries that significantly expanded cartel policies and they increase in size around the same time that actual cartel policies expand. In contrast, the estimated cartel shocks in countries that did not substantially change cartel policies are small. In these non-cartel countries, the cartel shock accounts for less than 20 percent of the change in employment, with monetary and productivity shocks accounting for most of the change. Aggregating the results over all seven countries, we find that cartel policies account for about 60 percent of the change in labor and about 40 percent of the change in output. We also find interesting interactions between cartel policies and monetary shocks that reflects nominal price and wage fixing in conjunction with deflation.

To our knowledge, this analysis makes new contributions in that it is the first crosscountry general equilibrium analysis of the Depression, it analyzes the contributions of multiple shocks, in contrast to the single-shock models that are common within the general equilibrium Depression literature, and the analysis presents a new model of monetary nonneutrality that facilitates the empirical analysis and provides new estimates on the quantitative importance of monetary shocks during the 1930s.

Exploiting the large cross-country differences in cartel policies noted above requires a common model framework. To construct a parsimonious and common model framework, we use the fact that many cartel policies, including those of the U.S., Italy, and Germany, are 
observationally equivalent to a country-specific wedge in the first order condition equating the marginal rate of substitution (MRS) between consumption and leisure to the marginal product of labor. Maximum likelihood is used to estimate the parameters of the MRS shock, which we hereafter refer to as the cartel shock, as well as other model parameters. The key hypothesis is that the countries that significantly increased cartel policies should have large and persistent negative cartel shocks that evolve over time according to the time variation in actual cartel policies, while the countries that did not pursue these policies will have cartel shocks that are around zero.

The model includes two additional shocks analyzed in the literature; monetary shocks operating through imperfectly flexible wages, as featured in Eichengreen and Sachs (1985) and Bernanke and Carey (1996), and productivity shocks, which have received attention in the recent literature (see Cole and Ohanian (1999) and Kehoe and Prescott (2002)). Wage inflexibility arises from imperfect information in which households must infer real wage changes from nominal wage changes, so that the size of the monetary nonneutrality can take on a range of values from a purely neutral model, to a model with a large nonneutrality. We estimate the size of the nonneutrality, which to our knowledge is new within the Depression literature, and more broadly, is new within the business cycle literature. Two versions of the model are analyzed, one with standard fixed capital utilization, and another with variable capital utilization. The latter model accounts for the possibility that the Solow Residual may reflect capital input mismeasurement.

The model fit for both the endogenous variables and for the money and productivity shocks is assessed using Kalman smoothing. Both versions of the model fit the data very well, accounting for on average more than 80 percent of the squared change in output, consumption, employment, investment, the money supply, and TFP. The maximum likelihood estimate of the size of the nonneutrality is fairly small in the fixed capacity version of the model, reflecting the fact that deflation is only modestly correlated with real variables, while the nonneutrality is larger in the variable capacity model, because monetary shocks account for some of the Solow Residual.

We conduct counterfactual experiments to assess two policy questions: (1) How much did cartel policies depress economic activity? (2) How much did leaving the gold standard promote recovery? We find that leaving gold earlier fostered a modestly faster recovery, but the gold departure date does not account for the fact depression continued in several countries after all countries were reflating. We find that cartel policies were a major depressing factor, particularly for understanding the differences in economic performance after 1932. If cartel policies had not been adopted, the Depressions in those countries would have been much milder and economic recovery would have been much faster.

The paper is organized as follows. Section 2 discusses the motivation for a common model and shows how cartel policies can be modelled as a marginal rate of substitution wedge that facilitates developing such a common model. Section 3 describes the data. Section 4 presents the model economy. Section 5 presents the quantitative methodology and section 6 presents the findings. Section 7 conducts the two counterfactual experiments, and Section 8 concludes. 


\section{Modeling Cartelization Policies as Marginal Rate of Substitution Distortions}

Exploiting the large variability in these panel data is facilitated by using a model that is common across countries. This section shows that the different cartelization policies used in the U.S., Germany, Italy, and Australia, map into a marginal rate of substitution distortion that can be easily incorporated into a simple, common model framework. We first summarize the major cartel policies that were present in these countries, including (1) industrial cartels, (2) nominal wage and price fixing, and (3) changes in worker bargaining power.

For the US, these policies were present under Presidents Hoover (see Ohanian (2009) and Rose (2010)), and Franklin Roosevelt (see Cole and Ohanian (2004)). Both Presidents promoted monopoly and helped raise real wages above the levels that would have prevailed under competition. Hoover oversaw a high level of industrial cartelization, and developed a nominal wage maintenance policy that required that firms maintain nominal wages, even with declining prices, in order to receive protection from union organization. FDR continued cartelization policies once deflation ended with the National Industrial Recovery Act (NIRA), which provided industry with explicit monopoly power if firms immediately and substantially raised wages and agreed to collective bargaining. After the NIRA was declared unconstitutional in 1935, these policies continued with the Wagner Act, which led to large increases in unionization. Real wages rose significantly during this period, as did the relative prices of output from cartelized sectors.

Wage fixing and monopoly were also operative in Germany, under Hitler's New Plan, and in Italy, under Mussolini's Corporatist Plan. Regarding Italy, Giordano et al (2011) documents Fascist government intervention in Italian labor and product markets and the impact of those interventions on prices and wages. Italian policies fostered substantial cartelization, including laws that forbid expanding plants or creating new plants, and created obligatory, government-run labor unions that set wages by region. Tooze (2007) describes substantial intervention in German labor and product markets Hitler froze wages and salaries at Summer, 1933 levels, and regional labor trustees decided on future wage increases. Hitler also broke independent unions that year and expanded industry cartels.

To see how these policies can be mapped into a common framework of marginal rate of substitution distortions, note that in many competitive models efficient time allocation between market and non-market activities equates the marginal rate of substitution between consumption and leisure to the marginal product of labor, which in turn is equated to the real wage, $W / P$, and which in turn equates labor supply $\left(L^{s}\right)$ and labor demand $\left(L^{d}\right)$ :

$$
\begin{aligned}
M R S & =M P L=W / P \\
L & =L^{s}=L^{d}
\end{aligned}
$$

First, consider the impact of product market cartelization. Any deviation from perfect competition in product markets breaks this equality, since the relevant firm efficiency condition with imperfect competition equates the marginal revenue product to the wage, and not the marginal product, and thus depresses employment relative to competition. Thus, expanding product market monopoly increases this wedge, with $W / P=M R S<M P L$, though the labor market is clearing with $L=L^{s}=L^{d}$. 
Second, consider the union-cartel policies adopted by the United States, which increase worker bargaining power, as in Cole and Ohanian (2004). Expanding unionization also drives a wedge into this equation as higher worker bargaining power raises the wage and lowers employment. This means that labor is demand-determined, as households would choose to work more at the cartel wage if this was feasible, thus $M R S<M P L=W / P$, and $L=L^{d}<L^{s}$

Third, consider the case of nominal wage fixing. If the nominal wage is fixed such that the real wage is above the competitive level, then the result is the same as in the case of expanding unionization, with labor being demand-determined and households are at a corner in terms of labor supply. If the nominal wage is fixed such that the real wage is below market clearing, then labor demand exceeds labor supply, and employment is supply-determined. This also generates a wedge as employment is low relative to the marginal product of labor, thus $W / P=M R S<M P L$ and $L=L^{s}<L^{d}$.

Finally consider a policy of price fixing, in which final goods prices are fixed below the market clearing price and there is rationing. In this case, the marginal utility of consumption is greater than the price of the final good and $M R S<W / P$. Given this price and assuming competitive firms, then $M R S<M P L=W / P$.

Each of these distortions creates a wedge between the MRS and the MPL. Thus, time variation in the severity of a variety of cartelization policies will generate country-specific time variation in this wedge. We use this observational equivalence between these policies and the MRS wedge to construct a common model, and we use maximum likelihood to estimate the stochastic process for this wedge and their realizations across time and across countries. We use the timing and the degree of changes in cartelization policies to interpret these estimated wedges. Our hypothesis is that these wedges will be large in countries that adopted cartelization policies, that their size will evolve over time as actual policy evolves, and that the wedges will be roughly zero in countries that did not expand these policies. Finally, note that fixing the price of labor either above or below its competitive level generates a wedge which is observationally equivalent to an increase in labor income taxation.

\section{Data}

We analyze data from 18 countries. We focus on countries from North America and Europe, as they are two regions that are most widely studied in the literature. In terms of European countries, we began with roughly the same countries as in Bernanke and Carey (1996) and Bernanke (1995), and we then narrowed the list of countries to those that have consistent time series data for real GNP, the GNP deflator, the money stock (M1), and at least some of the following other standard macroeconomic variables: aggregate labor, consumption, investment, and TFP. This yielded 15 European countries and also the U.S., Canada, Australia and Japan. ${ }^{1}$

\footnotetext{
${ }^{1}$ In terms of selecting countries for the panel, we do not include Latin American countries. These countries differ along a number of dimensions, including very different long-run growth paths and large differences in the composition of output. Moreover, there is not as much availability for the data we require from Latin American countries. However, it would be interesting to study Latin America as there were significant institutional changes in some Latin American countries around this time that created considerable
} 
Data are available for all of these variables for seven countries: Australia, Canada, France, Germany, Italy, U.K., and the U.S. We hereafter call this group the main seven countries, which includes four countries with particularly large depressions: Canada, France, Germany, and the U.S. For the other 11 countries (Austria, Czechoslovakia, Denmark, Finland, Hungary, Japan, Netherlands, Norway, Spain, Sweden, Switzerland), consumption is available for 15 of 18 countries, investment is available for 17 of 18 countries, M1 is available for all of our countries, except for Austria in 1931 and 1936, and aggregate employment is available for only one country outside of the main 7 (Japan). We focus the analysis on the seven main countries with all data available, because this provides the most discipline in fitting the model to the data. We assess the robustness of these results by comparing them to those from the other 11 countries.

The dataset begins in 1929, which is around the start of the depression for most countries, and continues through 1936. We do not extend the analysis beyond 1936 because this is when anticipations of possible World War begin, and 1936 is also the start of the Spanish Civil War. ${ }^{2}$ For this 1929-36 period, all countries experienced a decline in economic activity and all experience at least some economic recovery. All of the output series are measured in per capita terms and are detrended using a 2 percent annual growth rate.

Figures 1 - 3 summarize the dispersion in these variables by plotting cross-country data for output, labor, and the deflator in the main seven countries, and output and prices are plotted for all countries in the appendix. The most striking feature of these data is their enormous cross-country dispersion in all of these variables. Specifically, real output change ranges from a cumulative decline of less than four percent (Denmark), to a 50 percent decline (Canada), nominal price changes ranges from modest inflation (Spain) to a 40 percent cumulative price decline (France), and labor ranges from around a five percent cumulative decline (UK) to a 30 percent cumulative decline (U.S.). This large variation is also present in the other variables.

The substantial data variation in this panel of countries provides a strong test of how well a parsimonious, common model framework can account for these large differences in the pattern and severity of depression across countries.

\section{The Model}

This section develops a very parsimonious model with three shocks, each of which follows from a theme within the literature: a monetary/deflation shock (operating through inflexible nominal wages, as in Bernanke and Carey (1996), among others), a TFP shock, as in Cole and Ohanian (1999) and Kehoe and Prescott (2002), among others, and a cartelization shock that creates a marginal rate of substitution wedge, as in Cole and Ohanian (2004), and Ohanian (2009), among others. ${ }^{3}$

non-market and cartel policies. Finally, as we note below, the countries that are in the panel do provide substantial variation in the pattern of depression and deflation across countries.

${ }^{2}$ Tooze (2007) notes that by the end of 1936, the threat of war had become so clear that Lloyds of London ceased trading in war cover on property (p.203). We do not extend the analysis beyond 1936 as this anticipation of war may impact the estimated contributions of the three shocks that are modeled.

${ }^{3}$ The model does not include other monetary/financial channels, because the estimated model fits the data very well, including the money supply and the Solow Residual. It would be of interest, however, to 
Money is introduced using a standard cash-credit good formulation and nominal wage inflexibility arises from an information imperfection, which yields a parameter that governs the size of the nonneutrality of money in the model. This parameter can take values ranging from a purely neutral model to a model with a very large nonneutrality. This parameter is estimated when we fit the model to the data. To our knowledge, estimating the size of monetary nonneutrality has not been done in the depression literature and thus the quantitative magnitude of this shock remains an open question. While we view imperfect information as a plausible channel for generating monetary nonneutrality during this time period, this model of nonneutrality can be more broadly considered as a simple way through which monetary shocks depress employment and that also drive a wedge between the MRS and the MPL.

Note that the model has two sources of the MRS/MPL wedge; the monetary shock, and a cartel shock, which is represented as a time varying tax on labor income. We consider two variants of the model for the contribution of TFP, one with standard fixed capacity, and one with variable capacity. We include the variable capacity model since it allows monetary shocks to account for some of the Solow Residual and thus will increase the explanatory power of money/deflation for real variables.

There is a large number of identical households who have preferences over sequences of a cash good, a credit good, and leisure. Preferences are given by:

$$
E \sum_{t=0}^{\infty} \beta^{t}\left\{\log \left(\left[\alpha c_{1 t}^{\sigma}+(1-\alpha) c_{2 t}{ }^{\sigma}\right]^{1 / \sigma}\right)+\phi \log \left(1-h_{t}\right)\right\},
$$

where $c_{1}$ is the cash good, $c_{2}$ is the credit good, and $1-h$ is non-market time. Money is used to acquire cash goods, and is the sum of initial money holdings $m_{t}$ and the transfer that it receives from the government. The household maximizes (1) subject to a wealth constraint and the cash-in-advance (CIA) constraint:

$$
\begin{gathered}
m_{t}+w_{t} X_{t} h_{t}+r_{t} k_{t}+\left(T_{t}-1\right) M_{t}+\left(1-X_{t}\right) w_{t} H_{t} \geq m_{t+1}+p_{t}\left[c_{1 t}+c_{2 t}+k_{t+1}-k_{t}\right], \\
p_{t} c_{1 t} \leq m_{t}+\left(T_{t}-1\right) M_{t} .
\end{gathered}
$$

The household's labor income $w_{t} n_{t}$ is subject to what we call a cartel policy shock $X_{t}$, which as noted above is modeled a labor tax, and in which $X_{t}<1$ denotes an increase in the labor tax. The proceeds of the labor tax shock are rebated to the household lump sum, denoted as $\left(1-X_{t}\right) w_{t} \bar{H}_{t}$, where $\bar{H}_{t}$ denotes per capita labor, which in equilibrium coincides with the representative individual's labor choice $h_{t}$. Nominal wealth is the sum of initial cash holdings $m_{t}$, labor income $w_{t} X_{t} h_{t}$, capital income $r_{t} k_{t}$, a lump-sum monetary transfer $\left(T_{t}-1\right) M_{t}$ where $T_{t}$ is the gross growth rate of the money stock, and the rebate $\left(1-X_{t}\right) w_{t} H_{t}$.

extend this study and analyze whether the estimated Solow Residual declines may reflect financial factors, as a number of recent models of financial imperfections focus on their impact on productivity (see Buera, Kaboski and Shin (2011), and Mendoza (2010)). We pursued this by measuring the correlation between the Solow Residual and the standard cross-country measure of financial distress for the 1930s, which is from Bernanke and James (1990). However, we found that the correlation between the Bernanke-James variable and the Solow Residual is close to zero. This finding indicates the that analyzing possible connections between the Solow Residual and financial factors requires detailed, country-specific analyses that extend well beyond the scope of this paper. 
The rental price of capital, $r_{t}$, is measured net of depreciation. The household finances cash carried forward, $m_{t+1}$ and purchases of cash goods, credit goods, and investment $\left(p_{t}\left[c_{1 t}+\right.\right.$ $\left.\left.c_{2 t}+k_{t+1}-k_{t}\right]\right)$.

Output is given by:

$$
Y_{t}=Z_{t}\left(U_{t} K_{t}\right)^{\gamma} H_{t}^{1-\gamma}
$$

where $U_{t}$ denotes capital utilization, $K_{t}$ is the capital stock, $N_{t}$ is labor input, and $Z_{t}$ is a technology shock that follows a first-order lognormal autoregressive process:

$$
Z_{t}=e^{\hat{z}_{t}}, \hat{z}_{t}=\rho_{z} \hat{z}_{t-1}+\varepsilon_{t}^{z}, \varepsilon_{t}^{z} \sim N\left(0, \sigma_{z}^{2}\right) \text {. }
$$

The resource constraint is

$$
C_{1 t}+C_{2 t}+X_{t} \leq Y_{t}
$$

The transition rule for capital is

$$
K_{t+1}=\left(1-\delta\left(U_{t}\right)\right) K_{t}+X_{t},
$$

where $\delta\left(U_{t}\right)$ is the depreciation function, and it is assumed that $\delta(U), \delta^{\prime}(U)$ and $\delta^{\prime \prime}(U)$ are all positive for the variable capacity model, otherwise $\delta$ is constant. Monetary policy is given by exogenous changes in the gross growth rate of money. ${ }^{4}$ The money stock follows a first-order lognormal autoregressive process:

$$
T_{t}=\bar{\tau} e^{\hat{\tau}_{t}}, \text { where } \hat{\tau}_{t}=\rho_{\tau} \hat{\tau}_{t-1}+\varepsilon_{t}^{\tau}, \varepsilon_{t}^{\tau} \sim N\left(0, \sigma_{\tau}^{2}\right)
$$

The change in the money stock at the beginning of the period is $\left(T_{t}-1\right) M_{t}$, and the total money stock at the beginning of the period is: $M_{t+1}=T_{t} M_{t}$.

The cartel policy shock follows a first-order lognormal autoregressive process:

$$
X_{t}=e^{\hat{x}_{t}}, \text { where } \hat{x}_{t}=\rho_{x} \hat{x}_{t-1}+\varepsilon_{t}^{x}, \varepsilon_{t}^{x} \sim N\left(0, \sigma_{x}^{2}\right) .
$$

Households choose labor supply at the beginning of the period without full information of the state, and this information imperfection generates monetary nonneutrality. Households observe the nominal wage and all of the aggregate state variables except the current realization of the innovations to the monetary and productivity shocks. Thus, they don't know the price level at the time they choose labor supply decisions, and face a signal extraction problem in inferring the real wage from the nominal wage.

We now describe the timing of information and transactions. The state of the economy is $S_{t}=\left(K_{t}, \hat{z}_{t-1}, \hat{\tau}_{t-1}, \varepsilon_{t}^{z}, \varepsilon_{t}^{\tau}, \hat{x}_{t}\right)$. The lagged shocks and their current innovations are included separately because the model requires that households choose labor supply before they observe $\left(\varepsilon_{t}^{z}, \varepsilon_{t}^{\tau}\right)$. There are two sub-periods. In the initial sub-period, the household knows its own state $\left(k_{t}, m_{t}\right)$, observes a subset of the state vector, $\bar{S}_{t}=\left(K_{t}, \hat{\tau}_{t-1}, \hat{z}_{t-1}, x_{t}\right)$, and observes the nominal wage. However, households do not know the realizations of the money

\footnotetext{
${ }^{4}$ Our specification of exogenous, contractionary monetary shocks is consistent with the view stressed in the International Depression literature that deflation was caused by exogenous monetary shocks resulting from the gold standard (see Bernanke (1995) and Eichengreen (1992)).
} 
supply or technology innovations. The representative firm knows the full state vector. ${ }^{5}$ The labor market opens, and households and firms make their labor market choices. In the second sub-period, the full state $\left(S_{t}\right)$ is revealed, households receive monetary transfer from the government, output is produced, and households acquire consumption and investment goods.

The firm's maximization problem includes the choice of utilization, where the rental payment for capital is net of depreciation. The static optimization problem is:

$$
\max _{K_{t}, N_{t}} p_{t} Z_{t}\left(U_{t} K_{t}\right)^{\gamma}\left(H_{t}\right)^{1-\gamma}-w_{t} H_{t}-r_{t} K_{t}-p_{t} \delta\left(U_{t}\right) K_{t}
$$

The conditions for labor and capital are standard, and the first condition for utilization is

$$
p_{t} Z_{t} \gamma\left(\frac{H_{t}}{U_{t} K_{t}}\right)^{1-\gamma}-p_{t} \delta^{\prime}\left(U_{t}\right) .=0
$$

which implies that utilization will be decreasing in the capital-to-labor ratio and increasing in productivity, $Z_{t}$. All of the shocks will lead to changes in utilization, and thus will change the Solow Residual, which is $Z_{t} U_{t}^{\gamma}$.

To construct a recursive formulation, we denote the law of motion for aggregate state denoted by $G\left(S_{t}\right)$, and we divide all date $t$ nominal variables by $M_{t-1} T_{t-1}$, which means that the normalized beginning of period money stock is one $\left(m_{t}=1\right)$, and implies the following relationship between the household's money choice in period $t\left(\tilde{m}_{t+1}\right)$ and the quantity of money they have at the beginning of period $t+1\left(m_{t+1}\right)$ :

$$
m_{t+1}=\tilde{m}_{t+1} / T_{t}
$$

This transition rule implies that the money stock is constant over time, and we denote this constant stock as $M{ }^{6}$

The Bellman equation for the household is:

$$
\begin{aligned}
& V\left(m_{t}, k_{t}, \bar{S}_{t}, w_{t}\right)= \\
& \max _{n_{t}} E_{\left(\bar{S}_{t}, w_{t}\right)}\left\{\begin{array}{c}
\max _{c_{1 t}, c_{2 t}, m_{t+1}, k_{t+1}} \log \left(\left[\alpha c_{1 t}{ }^{\sigma}+(1-\alpha) c_{2 t}{ }^{\sigma}\right]^{1 / \sigma}\right)+\phi \log \left(1-h_{t}\right) \\
+\beta E_{S t} V\left(m_{t+1}, k_{t+1}, \bar{S}_{t+1}, w_{t+1}\right)
\end{array}\right\}
\end{aligned}
$$

subject to

$$
m_{t}+w_{t} h_{t} X_{t}+r_{t} k_{t}+\left(T_{t}-1\right) M+\left(1-X_{t}\right) w_{t} \bar{H}_{t} \geq m_{t+1} T_{t}+p_{t}\left[k_{t+1}-k_{t}+c_{1 t}+c_{2 t}\right]
$$

\footnotetext{
${ }^{5}$ These assumptions about the household's information set and the firm's information set are natural to make as we are using this simple environment to stand in for a richer environment with heterogeneous consumer goods. In this richer environment, firms care about their product price, the state of their technology, and the rental prices of labor and capital. The households would care about the entire distribution of prices in the economy. It seems plausible that households would have imperfect information about the entire distribution at the start of the period. Therefore, we capture the larger informational frictions faced by households by assuming that firms know the full state vector, while households do not.

${ }^{6}$ We use this transition equation in the household's budget constraint, substituting $T_{t} m_{t+1}$ for $\tilde{m}_{t+1}$, which is equivalent to quoting prices relative to money.
} 


$$
m_{t}+\left(T_{t}-1\right) M \geq p_{t} c_{1 t}
$$

and subject to the stochastic processes for the shocks. In the first stage, households choose labor, given $\bar{S}_{t}$ and given the nominal wage. Thus, they optimally forecast the technology and monetary shocks from their information set $\left(\bar{S}_{t}, w_{t}\right)$. Their labor choice satisfies:

$$
-\phi /\left(1-h_{t}\right)+w_{t} X_{t} E\left\{\lambda_{t} \mid w_{t}, \bar{S}_{t}\right\}=0
$$

The household equates the marginal utility of leisure to the expected marginal utility of nominal wealth $\left(\lambda_{t}\right)$, scaled by the nominal wage and the cartel policy shock. This expectational equation is solved using standard signal extraction methods. To conserve space, we omit the definition of equilibrium, and refer the reader to the appendix. ${ }^{7}$

\subsection{The Nonneutrality of Money}

This section shows how the information imperfection generates monetary nonneutrality. For heuristic purposes, we consider an i.i.d. money shock. There are four equations presented in log-linearized form. The first equation is the household's labor-leisure first-order condition:

$$
\hat{w}_{t}+\hat{x}_{t}-\frac{\hat{h}_{t} H}{1-H}=-E\left\{\hat{\lambda}_{t} \mid \hat{w}_{t}, \bar{s}_{t}\right\},
$$

where capital letters are steady-state values, lower-case letters with carets are log-deviations from the steady state, and $\bar{s}$ is the restricted state vector $\left(\bar{s}_{t}=\left(\hat{k}_{t}, \hat{z}_{t-1}, \hat{\tau}_{t-1}\right)\right)$. With imperfect information, the household makes its labor supply decision by forecasting the logdeviation in the marginal value of nominal wealth $\left(\hat{\lambda}_{t}\right)$, conditioning on the log deviation in the nominal wage $\left(\hat{w}_{t}\right)$ and the restricted state vector, $\bar{s}$ The second equation is the firm's first-order condition for hiring labor,

$$
\hat{z}_{t}+\gamma\left(\hat{u}_{t}+\hat{k}_{t}-\hat{h}_{t}\right)=\hat{w}_{t}-\hat{p}_{t}
$$

third equation is the production function:

$$
\hat{y}_{t}=\hat{z}_{t}+\gamma\left(\hat{u}_{t}+\hat{k}_{t}\right)+(1-\gamma) \hat{h}_{t}
$$

The fourth equation is the optimal capital utilization level:

$$
\hat{u}_{t}=\frac{1}{v-\gamma} \hat{z}_{t}+\frac{1-\gamma}{v-\gamma}\left(\hat{h}_{t}-\hat{k}_{t}\right),
$$

where $v$ is the elasticity of depreciation with respect to utilization.

To understand the household's inference/signal extraction problem, note that the loglinearized equation for $\hat{\lambda}_{t}$ is given by

$$
\hat{\lambda}_{t}=D_{\lambda k} \hat{k}_{t}+D_{\lambda z} \hat{z}_{t-1}+D_{\lambda \tau} \hat{\tau}_{t-1}+D_{\lambda \varepsilon} \varepsilon_{t}^{z}+D_{\lambda \varepsilon^{\tau}} \varepsilon_{t}^{\tau}+D_{\lambda x} \hat{x}_{t}
$$

${ }^{7}$ The online Appendix also considers a standard predetermined wage version of the model which has an even larger nonneutrality. Because of this larger nonneutrality, this version of the model fits the data worse than either of the versions of the model consider in this paper. 
where $D_{\lambda j}$ is the linearized coefficient for state variable $j$. Similarly, the log-linearized wage equation is given by

$$
\hat{w}_{t}=D_{w k} \hat{k}_{t}+D_{w z} \hat{z}_{t-1}+D_{w \tau} \hat{\tau}_{t-1}+D_{w \varepsilon^{z}} \varepsilon_{t}^{z}+D_{w \varepsilon^{\tau}} \varepsilon_{t}^{\tau}+D_{w x} \hat{x}_{t}
$$

Given $\bar{s}_{t}$ and $\hat{w}_{t}$, the workers forecast

$$
\hat{\lambda}_{t}-E\left\{\hat{\lambda}_{t} \mid \bar{s}_{t}\right\}=D_{\lambda \varepsilon^{z}} \varepsilon_{t}^{z}+D_{\lambda \varepsilon^{\tau}} \varepsilon_{t}^{\tau}
$$

from observing

$$
\hat{w}_{t}-E\left\{\hat{w}_{t} \mid \bar{s}_{t}\right\}=D_{w \varepsilon^{z}} \varepsilon_{t}^{z}+D_{w \varepsilon^{\tau}} \varepsilon_{t}^{\tau} .
$$

The solution to this standard signal extraction problem is

$$
E\left\{\hat{\lambda}_{t} \mid \hat{w}_{t}, \bar{s}_{t}\right\}-E\left\{\hat{\lambda}_{t} \mid \bar{s}_{t}\right\}=\eta\left[\hat{w}_{t}-E\left\{\hat{w}_{t} \mid \bar{s}_{t}\right\}\right]
$$

where $\eta$ is the signal extraction parameter to be defined. Rewriting this equation yields

$$
E\left\{\left(D_{\lambda \varepsilon^{z}} \varepsilon_{t}^{z}+D_{\lambda \varepsilon^{\tau}} \varepsilon_{t}^{\tau}\right) \mid\left(D_{w \varepsilon^{z}} \varepsilon_{t}^{z}+D_{w \varepsilon^{\tau}} \varepsilon_{t}^{\tau}\right)\right\}=\eta\left(D_{w \varepsilon^{z}} \varepsilon_{t}^{z}+D_{w \varepsilon^{\tau}} \varepsilon_{t}^{\tau}\right) .
$$

The optimal forecast of $\hat{\lambda}_{t}$ is given by

$$
E\left\{\hat{\lambda}_{t} \mid \hat{w}_{t}, \bar{s}_{t}\right\}=\left[D_{\lambda k}, D_{\lambda z}, D_{\lambda \tau}, \eta D_{w \varepsilon_{z}}, \eta D_{w \varepsilon_{\tau}} D_{\lambda x}\right] * s_{t}
$$

where, the parameter $\eta$ is given by

$$
\eta=\frac{D_{\lambda \varepsilon^{z}} D_{w \varepsilon^{z}} \sigma_{\varepsilon_{z}}^{2}+D_{\lambda \varepsilon^{\tau}} D_{w \varepsilon^{\tau}} \sigma_{\varepsilon \tau}^{2}}{\left(D_{w \varepsilon^{z}}\right)^{2} \sigma_{\varepsilon z}^{2}+\left(D_{w \varepsilon^{\tau}}\right)^{2} \sigma_{\varepsilon \tau}^{2}} .
$$

The parameter $\eta$ is the nonneutrality parameter, and depends on the variances of the shock innovations and on linearization coefficients. This parameter lies between 0 (maximum nonneutrality) and -1 , in which money is neutral. It is 0 when the variance of money shocks is 0 ; with log utility, a productivity shock has no effect on the marginal value of nominal wealth, and thus $D_{\lambda \varepsilon^{z}}=0$. It is -1 when the variance of productivity shocks is 0 . In this case money shocks raise the nominal wage one-for-one, ceteris paribus, and reduce the marginal value of nominal wealth one-for-one $\left(D_{w \varepsilon^{\tau}}=1\right.$, and $\left.D_{\lambda \varepsilon^{z}}=-1\right)$.

More specifically, consider an unanticipated decline in money that ultimately lowers the price level by 10 percent. This implies that the nominal wage must immediately fall to clear the labor market. If $\eta=-1\left(\sigma_{z}=0\right)$ then money is neutral, as the nominal wage also falls 10 percent, which leads workers to raise their forecast of $\hat{\lambda}_{t}$ by 10 percent. Consequently, there is no change in any real variable. Next, consider the same decline in money, but with $\eta=0\left(\sigma_{\tau}=0\right)$, which is the highest nonneutrality. The nominal wage must fall to clear the labor market, but in this case the household infers that the lower nominal wage is entirely due to a negative real shock, rather than a lower money supply. This misperception that the real wage has declined leads households to reduce labor. Consequently, the equilibrium 
nominal wage falls less than the price level, the real wage rises, and employment, utilization, and output all decline. ${ }^{8}$

We close this section by explaining why money demand shocks, which change the demand for currency, are not included in the model. We did not add them as it appears that on average they are quantitatively small. To see this, note that including money demand shocks modifies the CIA constraint with a stochastic shifter, $\xi_{t}$, that affects the extent that cash is required to purchase goods, as follows:

$$
\xi_{t} p_{t} c_{1 t} \leq m_{t}+\left(T_{t}-1\right) M_{t},
$$

The term $T_{t} M_{t} / \xi_{t}$ is the effective money supply, and fluctuations in the effective money supply work exactly like fluctuations in the money supply in the model without $\xi_{t}$. Thus, positive money demand shocks will have exactly the same effect as negative money supply shocks. Therefore, the relevant money object in the model is the effective money supply, which will be well approximated by the actual money supply if money demand shocks are small. We will later show that the money supply generated by the model without money demand shocks accounts for about 80 percent of the actual change in money in the panel dataset. This suggests that on average M1 money demand shocks are small.

Since the estimation fits the model money supply to M1 data, it is important to note that the money demand shocks we consider here are shocks that change the relationship between real M1, the opportunity cost of holding money, and consumption, rather than the shocks to the currency-deposit ratio emphasized by Friedman and Schwartz (1963) for the U.S. Changes in the currency-deposit ratio will show up in our analysis as negative money supply shocks that reduce M1. Thus small M1 money demand shocks are consistent with large changes in the currency-deposit ratio.

\subsubsection{Distinguishing between MRS wedges created by cartel policies or defla- tionary money shocks}

Both cartel policies and unanticipated monetary shocks in the model will drive a wedge between the marginal rate of substitution and the marginal product of labor. These two distinct sources of MRS distortions can be separately identified, as the monetary channel creates this distortion through money shocks, while cartel policies will be identified as the component of the wedge that cannot be accounted for in the model by money shocks.

\footnotetext{
${ }^{8}$ By comparison, in the predetermined wage model, households forecast the marginal value of nominal wealth given only the restricted state vector, $\bar{s}_{t}$, and the analog of $(3)$ in the predetermined wage model is given by:

$$
\hat{w}_{t}+\hat{x}_{t}-\frac{\hat{n}_{t} N}{1-N}=-E\left\{\hat{\lambda}_{t} \mid \bar{s}_{t}\right\} .
$$

In the predetermined wage model, the difference is that households forecast the marginal value of nominal wealth given only the restricted state vector, $\bar{s}_{t}$. However, the other equations governing the impact of a monetary shock, (4, 6) are unchanged. The steady state version of (4) is changed to include the mark-up which is governed by $\theta$. This means that a contractionary money shock qualitatively works the same way in the two models.
} 
Specifically, an MRS wedge from a money shock operates through the household's forecast error for the marginal value of nominal wealth. The difference between the marginal rate of substitution and the wage depends on the error in forecasting the marginal value of wealth, which in turn depends on the size of the productivity and money shock innovations and the linearization coefficients. Equations (7) and (8) yield:

$$
\begin{aligned}
\hat{\lambda}_{t}-E\left\{\hat{\lambda}_{t} \mid \hat{w}_{t}, \bar{s}_{t}\right\} & =D_{\lambda \varepsilon^{z}} \varepsilon_{t}^{z}+D_{\lambda \varepsilon^{\tau}} \varepsilon_{t}^{\tau}-\eta\left[D_{w \varepsilon^{z}} \varepsilon_{t}^{z}+D_{w \varepsilon^{\tau}} \varepsilon_{t}^{\tau}\right] \\
& =\varepsilon_{t}^{z}\left[D_{\lambda \varepsilon^{z}}-\eta D_{w \varepsilon^{z}}\right]+\varepsilon_{t}^{\tau}\left[D_{\lambda \varepsilon^{\tau}}-\eta D_{w \varepsilon^{\tau}}\right]
\end{aligned}
$$

Substituting, noting that $D_{\lambda \varepsilon^{z}}=0$ and noting that $D_{\lambda \varepsilon^{\tau}}=-1$ yields

$$
\hat{\lambda}_{t}-E\left\{\hat{\lambda}_{t} \mid \hat{w}_{t}, \bar{s}_{t}\right\}=\varepsilon_{t}^{z}\left[0-\eta D_{w \varepsilon^{z}}\right]+\varepsilon_{t}^{\tau}\left[-1-\eta D_{w \varepsilon^{\tau}}\right]
$$

Consider the case of the maximum nonneutrality, $\eta=0$. In this case, there is a MRS wedge, which is equal to the money shock $\varepsilon_{t}^{\tau}$. More generally, since the forecast error in the marginal value of wealth is due to a forecast error in predicting inflation/deflation, then the impact of a money shock on this wedge depends on the size of the forecast error.

Identifying the source of MRS distortions as either money shocks or cartel policies is based on the statistical relationship between deflation and the MRS/MPL wedge. If the correlation between the wedge and deflation forecast errors is 1 , then the wedge will be attributed entirely to monetary surprises and not cartelization policies. In contrast, if the wedge and deflation forecast errors are unrelated, then the wedge will be attributed to cartel policies. We will later see that the correlation between the cartel policy shock and money shocks are nearly zero, indicating that cartel policies are the key factor.

It is important to note that some cartel policies, such as Hoover's nominal wage fixing policy (see Ohanian, 2009), may be identified as nonneutral monetary shocks operating through the misperceptions channel, rather than cartelization shocks. This would tend to understate the importance of cartel policies in the model estimation. We address this issue by comparing the correlation between deflation and real variables for countries in which cartel policies explicitly involved fixing nominal wages and/or prices. We will see that the correlation between deflation and output in the cartel countries is stronger than in other countries, which is consistent with this view.

Finally, note that our approach of treating the component of the wedge that is unrelated to monetary shocks as cartelization policies may tend to overstate their importance if the non-monetary wedge component reflects other factors as well. To address this latter issue, we describe the details of actual cartel policies across countries and how those policies varied over time to assess the plausibility of interpreting the estimated wedges this way.

\section{Quantitative Methodology}

Our quantitative methodology consists of choosing parameter values and evaluating the fit of the model by measuring the percentage of squared change in each variable from 1929 values. Standard parameter values are used where possible. Other parameters are estimated using maximum likelihood. 
The model has a standard state space representation:

$$
\begin{aligned}
\zeta_{t+1} & =F \zeta_{t}+\varepsilon_{t}, \quad \varepsilon_{t} \sim \text { i.i.d.N }(0, \Omega) \\
a_{t} & =\nu \zeta_{t}+u_{t}, \quad u_{t} \sim i . i . d . N(0, \Sigma) \\
\zeta_{t} & =\left[k_{t}, z_{t-1}, \tau_{t-1}, \varepsilon_{t}^{z}, \varepsilon_{t}^{\tau}, x_{t}, m_{t}\right]^{\prime} \\
\varepsilon_{t} & =\left[\varepsilon_{t}^{z}, \varepsilon_{t}^{\tau}, \varepsilon_{t}^{x}\right]^{\prime} \\
a_{t} & =\left[y_{t}, p_{t}, c_{t}, i_{t}, n_{t}, z_{t}, m_{t}\right],
\end{aligned}
$$

in which $\zeta$ are the states, $a$ is the observation vector, $\varepsilon$ are white noise innovations to the states, and $u$ are measurement errors. Kalman smoothing is used to assess model fit in which the values of the states at each date are inferred given the estimated model and the full history of data. This assesses the fit of both the endogenous variables and the state variables.

Table 1 shows the values for the parameters which we choose a priori. Of these, the choices for the parameters that govern capital's share in production, $\theta$, the discount factor, $\beta$, market time allocation, $\phi$, autocorrelation of the productivity shock, $\rho_{z}$, the elasticity of money demand, $\sigma$, are common in the business cycle literature and are used in both the fixed and variable capacity versions of the model.

For the fixed capacity version of the model, the depreciation rate, $\delta$, is seven percent. For the variable capacity model, the depreciation rate schedule is given by:

$$
\delta(U)=B U^{v}, v>1
$$

The parameter $v$, which governs the elasticity of capital utilization is set to 1.1 , which is recommended by King and Rebelo (1999). We highlight this near-linear value because it yields a very high elasticity for capital utilization in response to shocks, and means that monetary shocks may account for a substantial fraction of the Solow residual in the variable capacity model. The scale parameter $B$ is then set so that the steady state depreciation rate is also seven percent.

Table 1

\begin{tabular}{|c|c|c|c|c|c|c|}
\hline$\theta$ & $\beta$ & $\alpha$ & $v$ & $\sigma$ & $\phi$ & $\rho_{z}$ \\
\hline .33 & .95 & .50 & 1.1 & .92 & 2 & .80 \\
\hline
\end{tabular}

We estimate the remaining parameters for both versions of the model using maximum likelihood. The MLE parameters are the autoregressive parameters for the money and cartel policy process, $\rho_{\tau}, \rho_{x}$, the standard deviations of the three shock processes, $\sigma_{z}, \sigma_{\tau}$, and $\sigma_{x}$, and the standard deviations of the measurement errors. This is a Kalman filtering/smoothing problem. Shumway and Stoffer's (1982) algorithm is used, which accommodates the fact that countries outside of the main seven do not have data on all of the variables. The appendix presents details of the estimation.

The state shock innovations are specified as independently distributed random variables. The estimated money innovations will be correlated across countries, however, reflecting the 
unusual event of worldwide deflation. This is unimportant for our analysis because the model with the i.i.d. shock specification is observationally equivalent to the model with shocks that are correlated across countries, in which the innovations are the sum of a common shock and a country specific shock. The appendix shows this equivalence.

Before turning to the results, we note that the variable capacity model can fit output and labor perfectly, which partially reflects the fact that the depreciation schedule is nearly linear. We retain the near linearity of depreciation to provide a very elastic capacity utilization schedule to enhance the quantitative importance of monetary shocks. We therefore follow the literature and pre-specify the measurement error variances for these two variables. This approach is recommended by Anderson et al (1996), and has been used by Caldara et al (2012), and Sargent (1989), among others. We found that the results are not very sensitive to the size of these measurement error variances over a plausible range. ${ }^{9}$

\section{Findings}

This section presents the fit of the model, the estimated parameters, with a focus on the estimated nonneutrality of money and the cartel policy shock process and the relative importance of each of the shocks for understanding the evolution of real variables and deflation.

To summarize, both the fixed and variable capacity versions of the model fit the data well. The size of the estimated nonneutrality is small in the fixed capacity model, and is moderate in the variable capacity model. In both models, monetary shocks account for virtually all of the change in deflation, account for a modest amount of the changes in real variables during the early stages of the depression, but account for very little of the change in real variables after 1933. Perhaps the most striking finding is that the cartel policy variable, rather than productivity shocks or money/deflation, is the most important factor in accounting for changes in employment.

\subsection{Model Fit}

Table 2 shows the fit of both the fixed and variable capacity models by showing the explained percentage of the cumulative squared change of each variable from its 1929 value. This measure of fit is equivalent to an R-square, but without a constant term. Hereafter we call this measure of fit "pseudo-R square".

Both models fit the data well, with the model accounting for between 70 percent to 99 percent of the squared change across most variables. Recall that we do not feed productivity and money shocks from the data, as is commonly done in the business cycle literature. Rather, the Kalman-smoothed productivity and money shocks fit the actual money and productivity data well. This means that the model estimation infers money and productivity shocks that are similar to actual money and productivity changes. ${ }^{10}$ In terms of fitting the

\footnotetext{
${ }^{9}$ We examined the results using different noise variances on output and labor, ranging from .005 , which is about the size of the estimated noise variances for the deflator and consumption, to .03. The findings are very similar.

${ }^{10}$ Note that we do not fit the labor policy shock. This is because it is the deviation from a linear combination of output, consumption, and labor, which are already being fit.
} 
model to data, we fit the Solow residual. This corresponds to TFP in the fixed capacity model but not in the variable capacity model.

Table 2 - Cumulative Explained Share of Squared Variable Change

\begin{tabular}{|l|l|l|l|l|l|l|l|l|}
\hline & \multicolumn{3}{|c|}{ Variable Capacity } & \multicolumn{4}{c|}{ Fixed Capacity } \\
\hline & \multicolumn{2}{|c|}{ Main 7 } & \multicolumn{1}{|c|}{$\mathbf{1 8}$ Countries } & \multicolumn{2}{c|}{ Main 7 } & \multicolumn{1}{c|}{ 18 Countries } \\
\hline & 1932 & 1936 & 1932 & 1936 & 1932 & 1936 & 1932 & 1936 \\
\hline Output & 0.97 & 0.98 & 0.95 & 0.97 & 0.99 & 0.99 & 0.98 & 0.99 \\
\hline Prices & 0.94 & 0.95 & 0.93 & 0.95 & 0.92 & 0.94 & 0.92 & 0.95 \\
\hline Cons. & 0.78 & 0.88 & 0.74 & 0.82 & 0.84 & 0.92 & 0.82 & 0.87 \\
\hline Inv. & 0.62 & 0.71 & 0.65 & 0.71 & 0.67 & 0.74 & 0.67 & 0.69 \\
\hline Labor & 0.95 & 0.97 & 0.95 & 0.97 & 0.96 & 0.97 & 0.96 & 0.97 \\
\hline Solow Residual & 0.99 & 0.99 & 0.99 & 0.99 & 0.96 & 0.96 & 0.96 & 0.96 \\
\hline Money & 0.82 & 0.81 & 0.74 & 0.78 & 0.82 & 0.78 & 0.75 & 0.77 \\
\hline
\end{tabular}

The close fit of the model is important because the model and its parameter values are common across countries, but recall the enormous cross-country dispersion present in all the variables. ${ }^{11}$ To further assess the model's fit, we compare the fit across different partitions of the data. First, note that the fit of the model is similar for both the main 7 countries, which include all data, and the entire panel of 18 countries. We first partition the data between the downturn (through 1932) and recovery phases (1933 and after). Table 2 shows that the model fits these two phases about equally well. We next partition the data across different sets of countries. This partition compares the fit between the main 7 countries and all of the countries. Table 2 shows that these fits are very similar. The next partition separates countries with large downturns (countries with cumulative output decline above the median in 1932) from those with smaller downturns. Both models fit both sets of countries equally well. We also partitioned countries into two other groups, one with countries that remained on gold until at least mid-1932 and the other with countries that left gold before that. Both models also fit these two groups equally well. These results indicate that a parsimonious model that is common across countries provides an empirically accurate framework for analyzing the very large differences in the size and nature of the Great Depression across these countries.

\subsection{Parameter Estimates}

Table 3 reports the autoregressive parameter values and their standard errors for the innovations of the three shocks. There are three particularly noteworthy parameter estimates, two of which govern the stochastic process for the cartel shock. Specifically, the shock is volatile, with a standard deviation that is larger than money and productivity shocks, and the cartel shock is also very persistent with an autoregressive parameter of 0.8 . Finally, note that money growth is serially uncorrelated. $\left(\hat{\rho}_{\tau}=0\right)$. This means that changes in money growth are unperceived, which generates larger money shocks, ceteris paribus, compared to those with $\rho_{\tau} \neq 0$. The third key parameter is the nonneutrality parameter, $\eta$, which is a

\footnotetext{
${ }^{11}$ Moreover, there are other large cross-country differences, including large differences in per-capita income, the relative importance of sectoral output, and in trade shares.
} 
function of the innovation variances of the money and productivity shocks, and ranges between -1 (neutral) and zero (maximum non-neutrality). It is estimated at -0.93 for the fixed utilization model, which is nearly neutral. At this value, a 10 percent unexpected deflation reduces output by about 1.5 percent, compared to the maximum possible impact of about 11 percent lower output in this model. In the variable capacity model, a 10 percent unexpected deflation reduces output by 7 percent, compared to the maximum possible impact of about 20 percent lower output when this parameter is at its highest nonneutrality.

Table 3 - Estimated Autoregressive Shock Parameters $(\rho)$ and
Innovation Standard Deviations $\left(\sigma_{\varepsilon}\right)$
\begin{tabular}{|l|l|l|l|l|}
\hline & \multicolumn{2}{|c|}{ Variable Capacity } & \multicolumn{2}{c|}{ Fixed Capacity } \\
\hline & $\rho$ & $\sigma_{\varepsilon}$ & $\rho$ & $\sigma_{\varepsilon}$ \\
\hline$\hat{z}$ & 0.80 (fixed a priori) & 0.03 & $0.80($ fixed a priori) & 0.04 \\
\hline$\hat{\tau}$ & 0.00 & 0.05 & 0.00 & 0.05 \\
\hline$\hat{x}$ & 0.80 & 0.05 & 0.80 & 0.05 \\
\hline
\end{tabular}

In the variable capacity model, the estimated cartel policy shocks are uncorrelated with monetary shocks (-0.04) and negatively correlated with the TFP shock (-0.53), while the TFP and money shocks are moderately correlated (0.44). In the fixed capacity model, the labor shock is weakly correlated with the money (0.10) and TFP (-0.26) shocks, but the money and TFP shocks are correlated (0.66).

It is not surprising that there is correlation between some of the shocks, as this is an unusual period with depressions and unusual economic policies in several countries. However, note that the cartel policy shock is uncorrelated with the money shock. This lack of correlation is the consequence of ML implicitly decomposing the labor wedge into two uncorrelated components, one due to deflation and another component that we identify as cartel policies. If the estimated nonneutrality was higher, then the monetary shock would be negative correlated with the cartel policy shock, as otherwise the two pieces would generate too large of a decline in labor. Similarly, if the nonneutrality was smaller, then the monetary shock and cartel policy shock would be positively correlated in order to account for labor.

We now discuss the estimated cartel policies in detail, and then discuss the size of the estimated nonneutrality of money.

\subsection{Estimated Cartel Policies and the Relationship with Actual Policies}

The estimation yields a volatile stochastic process for the cartel policy shock that generates large realizations of this shock for a number of countries. Figures 5 and 6 show plots of the Kalman-smoothed realizations of the labor shocks in both models. A negative shock is equivalent to an increasing labor income tax, thus depressing labor. One reason that the estimated cartel policy shock is quantitatively important in some of these countries is because money and TFP shocks are not strongly correlated with labor, and thus these latter two shocks cannot account for the bulk of labor fluctuations over the period. Figure five shows that there is a sizeable correlation between labor and deflation only in 1931 and 1932, 
and between labor and TFP only in 1930. We will see in the next subsection that the cartel policy shock is the primary driver of labor fluctuations.

Table 5 - Correlation Between Labor and Deflation and Labor and TFP
\begin{tabular}{|l|l|l|l|l|l|l|l|}
\hline & (Main 7 Countries) \\
\hline & 1930 & 1931 & 1932 & 1933 & 1934 & 1935 & 1936 \\
\hline Correlation $(l, \pi)$ & 0.17 & 0.48 & 0.86 & -0.17 & -0.49 & 0.13 & -0.14 \\
\hline Correlation $(l, t f p)$ & 0.76 & 0.00 & 0.22 & 0.38 & 0.24 & 0.00 & -0.04 \\
\hline
\end{tabular}

The figures show that the US, Germany, and Italy have large, negative labor shocks which grow during the downturn and continue to grow during the recovery. Australia has a negative shock that grows during the downturn, but then moderates during the recovery, and the UK, France, and Canada have only small shocks. Note that the cartel policy shock pattern for Germany, Italy, and the U.S. differs sharply from the average pattern observed during postwar U.S. business cycles, which is a modest increase in the labor wedge during a recession, but with a reversal of the labor wedge during recovery (see Ohanian (2010)). We now show that the estimated cartel policy shocks from this model coincide with actual cartel policies in the 7 countries for which we have labor data.

United States. Cole and Ohanian (2004) and Ohanian (2009) document wage setting and cartelization policies under both Hoover and Roosevelt. These papers describe that the goal of those policies was to raise prices and wages, and they show how those policies are observationally equivalent to the wage tax in this model. Hoover asked employers to either maintain nominal wages or raise nominal wages and that in return, Hoover would protect firms from union wage demands ${ }^{12}$. Roosevelt explicitly pursued cartelization policies with the National Industrial Recovery Act, which allowed industry to collude provided that they immediately raises wages. This research also describes how wage and cartelization policies became more distorting under Roosevelt. This pattern of actual policy shifts dovetails with the model results, as figures 5 and 6 show that the model's cartel policy shock became increasingly negative after 1933, which coincides with Roosevelt's New Deal labor and industrial policies, including the National Industrial Recovery Act and the National Labor Relations Act. Cole and Ohanian (2004) find that these policies raised relative prices and real wages in the cartelized sectors by up to 25 percent by the late 1930s. These results are consistent with a growing labor wedge featuring high real wages, low consumption, and low employment.

Germany. Cartels and unions were established, and during the early 1930s, real wages rose as nominal wages were inflexible (see Fisher and Hornstein (2002) for a recent discussion). The rising real wage thus dovetails with an increase in estimated labor distortions in the model. German policies are also consistent with a large wedge after 1933. Labor policies changed substantially after Hitler took power and created new distortions in the German labor market both in terms of wage setting and nonmarket allocation of labor. Unions were dissolved on May 2 1933. Post-1933 wages were set by a political board known as the "Trustees of Labor" and real wages fell substantially and likely were well below marketclearing levels. For example, James (1986) notes "savage" nominal wage cuts after Hitler

\footnotetext{
${ }^{12}$ Ohanian (2009) documents that many large employers kept nominal wages fixed until late 1931. He also notes that Ford Motor Company raised nominal wages following Hoover's meeting.
} 
took power, and Bry (1960) reports that real wages under Hitler would ultimately fall to 1913 levels by World War II, despite the fact that productivity had increased considerably since 1913. .

Hitler also imposed large interventions that further cartelized German industry. Specifically, Hitler's "New Plan" regulated the access of all German firms to foreign raw materials, and this in turn led to subsidies that were controlled by compulsory business organizations created between 1934 and 1935 and that were coupled with a system of price controls.

James (1986) describes how the Trustees of Labor used non-market approaches to deal with worker scarcity and to allocate workers. Laws were passed in 1934 that prohibited hiring non-local labor in areas of high unemployment. Married women were officially discouraged from working and many were fired, which reflected the broad goal of sharply limiting doubleincome households. Unmarried women were offered marriage loans, which became outright grants if the woman became a "prolific mother". Workers who were dismissed from their jobs in the political and racial purge of 1933 could not register as unemployed. Workers under 25 were dismissed and replaced by men who were family fathers, and 130,000 jobs were impacted by this policy in 1935. Unemployed young workers were drafted into work corps and emergency work, which included about 870,000 workers in 1934. In February, 1935 a Work Book was introduced to be retained by employers to make it difficult for a worker to move to a new job in search of higher wages. In November, 1936 a decree prevented newspaper advertising for building and metal workers to limit competition.

These labor market distortions in Germany differ considerably before and after Hitler. Prior to Hitler, the key distortion was unions imposing inflexible nominal wages that raised wages above market-clearing levels, while after Hitler there were many labor market distortions, including policies that reduced competition for workers, policies that limited opportunities for workers, and policies that fixed wages below market-clearing levels.

Theory predicts that these pre and post-Hitler differences in distortions should result in systematic pre and post-Hitler differences in real wages. Specifically, inflexible nominal wages in the early stages of Depression should result in a labor wedge reflecting relatively high real wages, low employment, and low consumption, while the various Hitler distortions, including fixing wages below market-clearing, combined with limiting opportunities for workers as described above, should result in low real wages relative to labor productivity, low employment, and low consumption.

The German data are consistent with these predictions. Fisher and Hornstein (2002) report high real wages in the early stages of the German Depression. By 1936, however, following the Hitler distortions, real wages are nearly 20 percent below labor productivity. This suggests that real wages were significantly below market-clearing levels after Hitler, and that the German labor wedge of the mid-1930s was the result of the Hitler policies.

\section{Italy.}

Italy's Fascist government under Mussolini adopted many cartel interventions in Italian labor and product markets that significantly impacted those markets, and that were qualitatively similar to those in Germany, including limiting worker mobility, reducing the number of women workers, and insulating domestic industry from foreign competition.

Giordano et al (2011) document Italian cartelization and labor policies, which we summarize here. As in Germany, Italian policies initially raised real wages through inflexible union 
nominal wages and deflation. However, policies reduced real wages below market-clearing levels by the mid-1930s as labor was organized under obligatory Fascist unions whose leaders were selected by the government. Wages were set across regions and industries, and wages relative to productivity declined substantially around this time, including a seven percent mandatory cut in 1934, and the workweek was reduced to a maximum of 40 hours. In 1930 both employers and workers unions were integrated into 22 corporate groups based on their business activity, which ultimately ended independent unions.

Real wages followed a similar pattern as in Germany. Real wages declined by about 23 percent (Zamagni, 1994) between 1932 and 1936, which resulted in real wages falling by about 10 percent below labor productivity by 1936. Like Germany, our results suggest that labor market policies generated a wedge with wages that were above market-clearing levels in the early 1930s, and with wages that were below market-clearing levels in the mid-1930s.

Labor markets were also impacted by government quotas on the number of women working in particular industries, and the fact that worker mobility was limited, as workers had to be registered with the local employment office to be hired.

Giordano et al note that Italian industry cartels flourished after 1932, which was facilitated by a 1932 law that allowed a company controlling 70 percent of the market to request that the state impose industry rules on the entire market. In 1933, a law was passed forbidding plant expansion or creating new plants, which restricted entry. Moreover, in 1933 the IRI (Institute for Industrial Recovery) was created to finance failed companies. The IRI became a major stockholder in companies representing $40 \%$ of the stock market. Giordano et al show that cartel prices rose during the early 1930s.

The Italian government increased protectionist policies in 1932, and by 1935 the government set quotas for each imported good and also created a government monopsony for the importing coal, copper, tin and nickel. Following Italy's 1935 invasion of Ethiopia, the League of Nations imposed economic sanctions on Italy, which led to an import ban on products from countries that condemned Italy's actions in Ethiopia, and controlling raw material and primary goods export markets. In 1936 the government set a goal of autarky, and subsidized exploration of oil and gas and development of hydroelectric power. As with Germany, these policies represent significant distortions in labor and product markets.

Australia. The labor wedge in Australia displays an interesting pattern with a growing distortion in the early 1930s, but a narrowing distortion afterwards, and policy changes are also consistent with this pattern. Before the Depression, Prime Minister Stanley Bruce wanted to eliminate Australia's collective bargaining and arbitration system so that wages could respond more quickly to changes in labor market conditions. Since 1907, Australian wages had been set with a principle of paying "fair and reasonable" wages, at first to qualify for tariff protection, and later government tribunals set wages across regions, industries and occupations.

Bruce was easily defeated in the 1929 election by Labor Party candidate James Scullin, who had portrayed Bruce as an enemy of high wages and decent working conditions, as about half of the Australian workforce belonged to a union at that time. The growing labor wedge in the early 1930s is thus consistent with the incumbent system of wage setting, which generated rigid nominal wages, along with deflation. 
But rising unemployment and the rigidity of wage setting created the Federal Wage Judgement of 1931, which called for a 10 percent nominal wage cut. The Attorney General called for the judgement to be delayed, and de facto, a number of tribunals were very slow to implement the cut (Shedvin, 1970). Shevdin describes that over time, these nominal wage cuts were implemented. This fact, together with rising productivity, is clearly consistent with the decline in Australia's labor wedge in the mid and late 1930s. Thus, the estimated pattern of labor distortions that grow during the downturn and then recover later is consistent with actual Australian labor market policies in the 1930s.

We next describe policies in the countries that did not have significant estimated cartel policy shocks: UK, Canada, and France.

United Kingdom. The estimated model finds very little change in cartel policies in the U.K. relative to the 1929 value. This is consistent with the fact that to our knowledge there were no major new cartel/labor adopted policies adopted in the U.K. during the period of study. Specifically, Cole and Ohanian (2002) discuss large changes in unemployment benefits that were adopted in the early 1920s and thus would not impact the estimation that begins in 1929.

Canada. The estimated model finds no large labor distortion in Canada. This is consistent with the fact that there were no major cartel/labor policies adopted in Canada during the Depression. Specifically, Amaral and MacGee (2002) report that Canada did try to adopt cartel policies similar to the U.S. New Deal policies, but the Canadian policies were declared unconstitutional before they took affect. Amaral and MacGee also note that real wages declined modestly over the course of the Depression, which stands in sharp contrast to the very large increase in wages in the U.S. The fact that the estimated model little evidence of changes in cartel policies in Canada is consistent with the fact that Canada did not adopt significant cartel/labor policies during this period.

France. The estimation finds only modest deviations in France through 1936, and we are unaware of any significant increase in cartel/labor policies through this period. However, the Popular Front was elected in May, 1936, and this led to large changes in labor policy, including legislated higher wages, restriction on the workweek length, and collective bargaining rights. However, these factors primarily impacted France after the period which we analyze. Bridji (2012) studies the impact of the Popular Front on the French economy.

In summary, we find a very strong empirical relationship between actual cartel policy changes in the 1930s and the estimates of such distortions in the model. For the seven countries for which we have economy-wide measures of labor input, the U.S., Germany, and Italy all adopted very significant cartel/labor policies that tended to grow over time, and we estimate large increases in cartel policies in these countries that also tend to grow over time. Canada, France, and the U.K. did not significantly expand cartel policies, at least through the period we consider, and we estimate only small changes in cartel policies in these countries. Australia had widespread union polices in place in the early 1930s, but these policies were weakened afterwards. We estimate a significant labor distortion in the model in the early 1930s, but a reversal of that distortion afterwards, which is consistent with Australian policy. 


\subsubsection{Understanding the Size of the Estimated Nonneutrality}

This subsection analyzes the size of the estimated nonneutrality. Figure 4 shows the likelihoods for both the fixed and variable capacity models over the range of possible nonneutralities. The fixed capacity likelihood is steep around its optimum, as the model fit deteriorates substantially as the nonneutrality gets large. The variable capacity model likelihood is somewhat flatter, but the likelihood also deteriorates at higher nonneutrality values. To understand the implication of the size of the nonneutrality, we fixed the nonneutrality in the variable capacity model to nearly its highest value $(\eta=-.1)$, and estimated the other parameters. The fit of the model is poor after 1932, as the explanatory power of money shocks in this version of the model have a pseudo-R square for labor that is negative in 1935 and 1936. The key reason that the likelihood deteriorates at large nonneutrality values in both the fixed and variable capacity models is because there is a fairly weak relationship between deflation and real variables in the data, and a higher nonneutrality forces a counterfactually stronger relationship between these variables in the model.

Table 6 presents information on the weak statistical relationship between deflation and real output that explains why the nonneutrality is not larger. The table shows the fit of three regressions of real output on deflation, and the regression coefficient. The main result is that deflation is quantitatively unimportant in all of the regressions. The first regression, in which the log deviation of output from 1929 is regressed on the log change in the price level between $t-1$ and $t$, roughly approximates the output equation in our economic model, but without capital, the productivity shock and the cartel shock. The second regression adds country fixed effects to the first regression, in which the fixed effect is a proxy for omitted factors, such as the productivity and cartel shocks. The third regression includes just the fixed effect in order to test the importance of deflation. All of these regressions are nested in the following equation:

$$
y_{i t}=\alpha_{\pi} \pi_{t}+\beta_{i}+\varepsilon_{i t},
$$

in which $y$ is the log-deviation of output from 1929, and $\pi$ is the annual log change in the price level from period $t-1$ to $t$.With just deflation (regression 1), the R-squared with deflation is about .08. When the country fixed effect is included in the regression (regressions 2 and 3), deflation adds no incremental explanatory power.

Table 6 - Regressions of Output on Deflation
with and without Country Fixed Effects
\begin{tabular}{|l|l|l|}
\hline Regression & $\alpha_{\pi}$ & $R^{2}$ \\
\hline No Country Fixed Effects & 0.98 & .08 \\
\hline Country Fixed Effects & -.13 & .846 \\
\hline Country Fixed Effects Alone & & .845 \\
\hline
\end{tabular}

These findings show that deflation is not systematically related to output, particularly when conditioning on the country fixed effect. Specifically, note that deflation has virtually no incremental explanatory power beyond the country fixed effect. This indicates why a high nonneutrality results in a poor fit in the economic model. Specifically, a high nonneutrality forces a strong, positive relationship between log price change and output change, but this is at variance with the data. 
Next, we evaluate whether the empirical relationship between output and deflation may be responsible for why money shocks in the model have very little explanatory power after 1932. We calculated the R-squared for each year from the first regression presented above (the panel regression of output on log price change with no fixed effects, see Table 6 , first row, $\alpha_{\pi}=.98$ ). ${ }^{13}$ The R-squared is only positive in 1931 and 1932 (R-squared $=, 48$ and ,39, respectively). The R-squared is negative in 1930, and is also negative in 193336. Moreover, calculating the R-squared using a coefficient that is greater than the OLS coefficient of 0.98 , and which is akin to increasing the monetary nonneutrality in the economic model, exacerbates the poor explanatory power associated with the 1930 and the post-1932 observations. With a larger coefficient, The R-squared in 1931 and 1932 rises, but the R-squared becomes much more negative in 1930 and in 1933-36.

Taken together, these statistics show that the empirical relationship between deflation and output is a key reason why the estimated nonneutrality is small in the fixed capacity model, and is moderate in the variable capacity model (in which monetary shocks account for some of the Solow Residual). More broadly, these empirical relationships between output and deflation have important implications for the quantitative importance of money shocks, particularly after 1932, in other classes of models. The weak empirical relationship between output and deflation will also be important in understanding the model's evaluation of the impact of going off the gold standard. ${ }^{14}$

\subsection{Contributions of Individual Shocks}

This section reports the contributions of each shock individually. The main findings are as follows: monetary shocks account for virtually all of nominal price change, but are less important in accounting for real variables. They account for about 30 percent of output fluctuations in the early stages of the depression (1930-32), but have little explanatory power for real variables during the recovery (after 1933). TFP shocks are particularly important in accounting for output and consumption, but are much less important in accounting for labor. Cartel policy shocks are central in accounting for labor, explaining more than half of labor fluctuations in the latter stages of the Depression ${ }^{15}$.

We measure the individual contributions by feeding in each single shock into the estimated model and then calculate the percentage of squared change in the variables relative to their 1929 values. Tables $7 \mathrm{a}-7 \mathrm{~b}$ show the pseudo- $\mathrm{R}$ square for each year and for each of the three individual shocks. Money is quantitatively less important for real variables, particularly for the recovery period.

One hypothesis for why money is more important for the early Depression years is because

\footnotetext{
${ }^{13}$ We chose this regression since it provides the most transparent illustration of this feature of the data.

${ }^{14} \mathrm{We}$ assessed the robustness of the findings presented in Table 5 by assessing whether lagged deflation improves the explanatory power of deflation. It does for the regression without fixed effects, in which the $\mathrm{R}$-squared rises to 0.24 . However, the regression with the fixed effect is virtually unchanged when adding lagged deflation. This finding suggests that the nonneutrality of money in models in which there are lagged effects of monetary policy may not be much different than our estimates.

${ }^{15}$ Note that some table entries are negative, which means that the one shock in isolation predicts changes in that specific variable that yield larger forecast errors than a forecast of no change in the variable. This is expected. For example negative productivity shocks in isolation generate inflation, not deflation.
} 
cartel/labor policies in the U.S., Germany, Australia, and Italy in the early 1930s impeded nominal wage adjustment, which means that some of this factor may be accounted for by monetary shocks, rather than by cartel policy shocks. We assess this by comparing the correlation between output and deflation in two sets of countries, the U.S., Germany, Italy, and Australia, and for all other countries for 1930-32. If deflation was primarily affecting output through nominal wage fixing policies, then this correlation should be higher in the group of cartelized countries. We find that this is the case, as the correlation between log output change and log price change is .36 in Germany, Italy, Australia, and the U.S. for 1930-32, but is only -.04 for the other countries. This suggests that cartel policies may in fact be the key driving factor behind monetary nonneutrality early in the Depression.

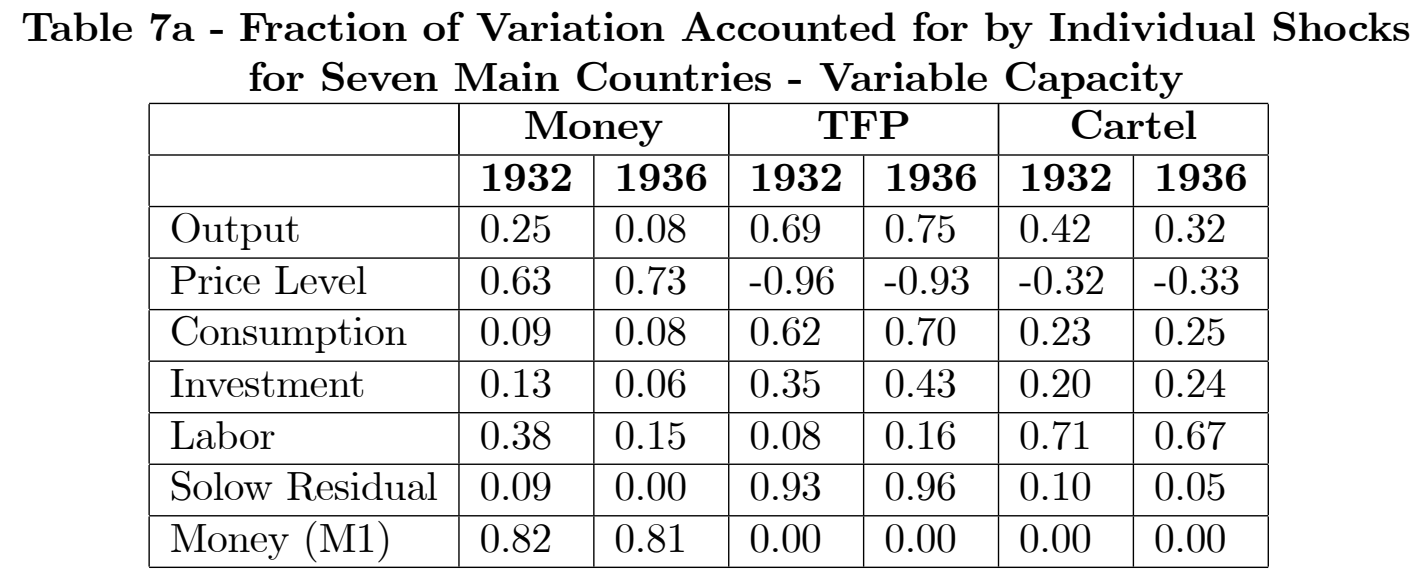

Table 7b - Fraction of Variation Accounted for by Individual Shocks for Seven Main Countries - Fixed Capacity

\begin{tabular}{|l|l|l|l|l|l|l|}
\hline & \multicolumn{2}{|c|}{ Money } & \multicolumn{2}{c|}{ TFP } & \multicolumn{2}{c|}{ Cartel } \\
\hline & $\mathbf{1 9 3 2}$ & $\mathbf{1 9 3 6}$ & $\mathbf{1 9 3 2}$ & $\mathbf{1 9 3 6}$ & $\mathbf{1 9 3 2}$ & $\mathbf{1 9 3 6}$ \\
\hline Output & 0.09 & 0.05 & 0.80 & 0.84 & 0.49 & 0.41 \\
\hline Price Level & 0.59 & 0.63 & -0.66 & -0.96 & -0.54 & -0.50 \\
\hline Consumption & 0.04 & 0.04 & 0.49 & 0.66 & 0.36 & 0.38 \\
\hline Investment & 0.06 & 0.04 & 0.51 & 0.60 & 0.23 & 0.26 \\
\hline Labor & 0.17 & 0.08 & 0.38 & 0.37 & 0.83 & 0.81 \\
\hline Solow Residual & 0.00 & 0.00 & 0.96 & 0.96 & 0.00 & 0.00 \\
\hline Money (M1) & 0.82 & 0.78 & 0.00 & 0.00 & 0.00 & 0.00 \\
\hline
\end{tabular}

The key difference between the fixed and variable capacity models is the decomposition of the Solow Residual across different shocks. In the fixed capacity model, the Solow Residual is TFP, and the model necessarily infers large declines in TFP in several countries. In contrast, the variable capacity model allocates some of the Solow Residual to money and cartel policy shocks, which results in much smaller TFP shocks. Specifically, TFP in the variable capacity model is above its 1929 level in 1933 in 4 of the main 7 countries. For the other three countries, TFP declines by only two percent in France, compared to a seven percent decline in the model's Solow Residual for France, and TFP declines four percent in 
the U.S. compared to a 16 percent decline in the model U.S. Solow Residual. Only Canada has a very large TFP decline (13 percent) in the variable capacity model. ${ }^{16}$

We also examined the robustness of the findings using a counterfactually high nonneutrality that had a much lower likelihood than the ML estimate. We fixed the value of $\eta$ to -0.1, which is nearly the highest nonneutrality in the model, and then estimated the other parameters. At this value of $\eta$, and with our estimated parameters, a $10 \%$ deflation lowered output by over $19 \%$. This raised the contribution of money shocks for real variables during the downturn but had very little effect on the contribution of money after 1932. Specifically, money accounts for 17 percent of output and 32 percent of labor through the entire period (1930-36), which is driven largely by the relationship through 1932, in which money accounts for 45 percent of the change in output and 67 percent of the change in labor through 1932. The wedge shock remains the dominant factor in accounting for labor after 1933, and the wedge shocks in the U.S., Germany and Italy are little changed with this alternative parameterization.

\section{The Impact of the Cartel Policies and the Gold Stan- dard}

This section conducts two counterfactual experiments: (1) What would have happened to output and labor in the three major cartel policy countries (US, Germany, Italy) had they not adopted cartel policies? (2) What would have happened to output and labor in the countries that left gold early had they instead stayed on gold and followed the monetary policies of the Gold Bloc countries (France, Netherlands, Switzerland)? We find that leaving gold fostered an earlier recovery with moderately higher output and labor through 1935, but after that. We find a very large and persistent impact of cartel policies on economic activity, particularly by the mid-1930s when almost all countries are reflating significantly. We discuss the experiments in detail below.

\subsection{The Impact of Cartel Policies}

To assess the impact of cartel policies, we construct a counterfactual which sets the cartel policy shock to zero each period in the countries with the most severe cartel policies: the US, Germany, and Italy. Note that by setting this shock to zero, we may be also eliminating other factors that are impacting the MRS/MPL distortion, and which could overstate the importance of eliminating cartel policies. However, the fact that there is no sizeable MRS/MPL distortion in the countries that did not significantly increase cartel policies in the 1930s suggests that much of this distortion in the U.S., Germany, and Italy may indeed reflect cartel policies.

\footnotetext{
${ }^{16}$ These TFP findings may suggest to some that the variable capacity model is more plausible than the fixed capacity model. However, the ML criterion prefers the fixed capacity model to the variable capacity model. Similarly, ML picks a very low depreciation elasticity parameter $(v)$ when we estimate this parameter in the variable capacity model, which delivers a likelihood that is much closer to that in the fixed capacity model.
} 
We therefore calculate output and labor in the variable capacity model under the counterfactual that the cartel policy shock is zero for each year. The analysis indicates that these three countries would have had much faster and stronger recoveries had they not adopted these policies. Specifically, removing the MRS/MPL distortion in the counterfactual experiment generates much higher levels of output and labor, particularly during the mid-1930s.

Figure 7 shows predicted output from the variable capacity model for the U.S., Germany, and Italy with and without the MRS/MPL distortion. This shows that the policy has a large impact in all of the countries in the model. In the U.S., model output without this distortion is more than twenty percent above its level with the distortion in 1936 . This predicted difference in the absence of these policies is similar to that reported in Cole and Ohanian's (2004) study of New Deal cartel policies. This is noteworthy because Cole and Ohanian developed an explicit model of New Deal monopoly and union policies, whereas these policies are modelled here simply as an MRS/MPL distortion in order to preserve the ability to use a common model in all countries.

Removing cartel policies have similar effects in both Germany and Italy. In Germany, removing the MRS/MPL distortion generates about an 18 percent difference in output by 1932, and this difference persists through 1936. By this year, the model without the distortion generates output that is about nine percent above trend, compared to output that is about eight percent below trend when the distortion is included. For Italy, there is about a 15 percent difference between output without the distortion and output with the distortion. Specifically, output in Italy in the counterfactual returns to trend by 1936, while output with the MRS/MPL distortion is about 15 percent below trend in 1936.

\subsection{The Impact of Leaving the Gold Standard}

There are several empirical analyses regarding the timing of leaving gold during the Depression and recovery, including Choudhri and Kochin (1980), Eichengreen and Sachs (1985), and Bernanke (1995), that document that countries that left gold earlier recovered faster and had less deflation than countries that stayed on gold. The countries analyzed here are among those that are analyzed in the papers above, and thus share this same empirical feature regarding recovery and leaving gold. ${ }^{17}$

Quantifying the impact of leaving gold is challenging because other factors may be changing at the same time, and the timing of when to leave gold may be endogenous. This section constructs a counterfactual experiment to isolate the impact of differences in monetary policy between on and off gold countries. We do this by imposing the monetary policy of the on-gold-countries on the off-gold countries, taking as given the TFP and cartel policy shocks, and we then calculate the differences in output under this counterfactual policy.

\footnotetext{
${ }^{17}$ It is important to note that the measures of output and deflation analyzed in this paper differ from those used in the literature, and in our view our measures are superior. Real GNP and the GNP deflator are used in this analysis, because they are measures of aggregate output and the nominal price of final output. The literature cited above typically uses industrial production as aggregate output, and a wholesale price index for the price of this output. Both of these choices are problematic, because these measures do not represent final aggregate output or its nominal price. Moreover, the composition of the components in wholesale price indices differ enormously across countries, and often are measures of raw input prices, not the nominal price of final output.
} 
We use the variable capacity model since money shocks have a larger impact on real variables and because this model closely captures the empirical relationship between output and prices. Specifically, the correlation between actual log output and log price is about 0.3 between 1932 and 1936, and is 0.27 for the model's Kalman smoothed realizations. Thus, the variable-capacity version of our model yields virtually the same modest empirical relationship between output and prices during this period in which some countries were on gold and some countries were off gold.

We quantify the impact on output and labor in each country outside the gold bloc by comparing output with their observed price path to that if they had instead followed the monetary policies of the gold bloc countries that did not leave gold until later. The countries are split into two groups: the gold bloc (France, Netherlands, Switzerland), and all other countries. For each of the countries leaving gold early, we define the year that they left gold as the year in which they were off gold for at least 20 percent of that year. Between the initial off-gold year and 1936, we construct the counterfactual money supply by year so that each of the earlier leaving countries has the same rate of log price change by year as the average for France, Netherlands, and Switzerland. We then compare output and labor each year under the counterfactual gold-bloc monetary policy to that under their observed price path. We hold fixed the time path of productivity and cartel policy shocks to isolate the impact of monetary policy.

We find that leaving gold early fostered an earlier recovery through a lower deflation rate than in the gold bloc. For example, the country with the smallest difference in deflation compared to the gold bloc was Germany. Germany's deflation rate was only about 1.5 percentage points less per year than the gold bloc, as Germany did not change their gold parity and instead had to adopt other policies, including foreign exchange controls. Because German deflation was fairly similar to that of the gold-bloc, there is only a small difference in output and labor under the counterfactual. In contrast, the U.K. had about five percentage points less deflation per year than the gold bloc through 1933, which in our model generates about four percent higher output in 1933 than if they had followed the gold bloc price path. The average peak output difference across all of the non-gold countries is about two percent, which also occurs by 1933 .

However, the counterfactual also indicates that the on-gold/off-gold distinction does not account for the continued difference in recovery between these two sets of countries after 1933. Specifically, the peak difference in output in the counterfactual between the off-gold policy and on-gold policy occurs for almost all countries in 1933. The differences from leaving gold early in the counterfactual are nearly gone after 1933, which is because almost all countries are realizing inflation after this date. Table 8 shows the pattern of actual cumulative log output changes and annual log price changes (annual deflation/inflation rate) between the on and off-gold countries between 1931 and 1936. The table shows that the off-gold countries have considerably less deflation in 1932 and 1933, but both sets of countries have about three percent inflation between 1933 and 1936. Since the off-gold countries had already reflated relative to the on-gold countries through 1933, monetary policy could only increase relative employment and output further in the off-gold countries by generating an even higher inflation difference after 1933. This did not occur, however, as both sets of countries had about the same rate of price change. 
The difference in post-1933 recovery between the on and off-gold countries, given that they have roughly the same inflation rates after 1933, suggests that the cartel and technology shocks are the primary factors for understanding post-1933 output differences between these two sets of countries. Specifically, the combination of the cartel and TFP shocks in the variable capacity model (and in which TFP is not the Solow Residual), explains at least $93 \%$ of the variation in output and at least $85 \%$ of the variation in labor in each year after 1933 for both sets of countries, with the cartel shocks being particularly important for the U.S., Germany, Italy, and Australia after 1933. Moreover, the fact that monetary shocks are fairly unimportant in the model after 1933 is not surprising, given that the empirical results presented earlier showed that the R-squared of output regressed on deflation was negative during these years.

\section{Table 8 - Average Log-Deviations in Output and the Price Level Growth for Countries On-Gold versus Off-Gold}

(Off-gold = leaving gold by June, 1932)

\begin{tabular}{|l|c|c|c|c|c|c|}
\hline Year & 1931 & 1932 & 1933 & 1934 & 1935 & 1936 \\
\hline On-Gold $Y$ & -0.12 & -0.22 & -0.23 & -0.25 & -0.24 & -0.24 \\
\hline Off-Gold $Y$ & -0.11 & -0.17 & -0.18 & -0.15 & -0.14 & -0.10 \\
\hline \hline On-Gold $\Delta p$ & -0.07 & -0.07 & -0.05 & -0.00 & -0.02 & 0.05 \\
\hline Off-Gold $\Delta p$ & -0.06 & -0.04 & -0.01 & -0.00 & 0.02 & 0.01 \\
\hline
\end{tabular}

\section{Summary and Conclusions}

This analysis exploited the very large cross-country differences in the severity of the Depression and in the expansion of cartel policies to estimate and test the contributions of these policies, as well as the contributions of monetary shocks and productivity shocks. Our main finding is that cartel policy shocks account for the bulk of the Depression in the countries that adopted significant cartel policies, including the large depressions in the U.S., Germany, Italy, and Australia, and that the estimated cartel policy shocks plausibly coincide with the actual evolution of policies in these countries. In contrast, cartel policy shocks in the countries that did not significantly change policies were small and account for little of their Depressions. Overall, cartel policies account for about 60 percent of the squared change in labor and about 40 percent of the squared change in output across all of the seven countries for which we have aggregate labor data.

We used both fixed and variable capacity utilization versions of an estimated monetary DSGE model in the analysis. Using Kalman smoothing, we find that both estimated versions of the model are empirically accurate. The models fit real output, consumption, investment, labor, and the price level closely, and it also fits the three shocks very well. In particular, the model accounts for around 80 percent of the money supply and more than 90 percent of TFP. While we do not have a direct empirical analogue of the cartel shock, the estimated cartel shock is empirically plausible, as it is estimated to be around zero in the countries that did not expand cartel policies, and is large, negative and evolves over time that is very similar to the actual evolution of these policies in the U.S., Germany, Italy, and Australia. These findings indicate that cartel, productivity, and monetary shocks are key factors in 
accounting for cross-country differences in the Depression. We emphasize that this does not mean that financial factors such as banking crises did not play a role. Rather, banking and financial factors may be contributing to TFP fluctuations, as in the models of Buera, Kaboski, and Shin (2011), and Mendoza (2010). Developing a model of TFP for analyzing changes in TFP during the Depression through financial channels is beyond the scope of this paper, but would be of interest for future research.

We focus on the variable capacity model since its higher estimated nonneutrality and the fact that it matches the cross-country pattern of output and price change particularly well, makes it a better tool for conducting the counterfactual experiments. These two experiments quantified the impact of leaving the gold standard on fostering recovery, which we found to be relatively modest, and quantified the impact of cartel policies, which we found to be very substantial. More specifically, leaving gold early does not account for the continuing large difference in economic performance across countries, because by the mid-1930s, all countries are reflating at roughly the same rate. The Depressions in these countries would have been milder and shorter-lived in the absence of cartel policies.

The main reason why the cartel shock is quantitatively important, particularly for labor, is because there are very few years in which either deflation or productivity are correlated with labor. These weak statistical associations means that neither money nor productivity systematically accounts for labor within the model. We assessed the empirical plausibility of the estimated cartel shocks by comparing the estimated size of the shocks, and how they changed over time, to actual cartel policies. Perhaps the most striking finding is that the estimated cartel shocks are large in the countries that had major cartel policies - the United States, Germany, Italy, and Australia, and that the estimated size of the shocks change over time according to the changes in actual policies. Specifically, estimated cartel shocks in the U.S., Germany, and Italy become larger as the actual policies in these countries expand, while the estimated cartel shock in Australia declines over time, as Australia reformed union wage setting policies.

Some of the explanatory power of the cartel shocks, as well as that of the money shocks, reflects complementarity between these two shocks, as policies that increase the rigidity of wages and prices will have much a larger impact in the presence of a large deflation. Consistent with this view is that the countries that had large cartel shocks also had a substantially stronger correlation between deflation and output than the other countries.

While our findings suggest a relatively small direct role for monetary shocks, which reflects the fact that there is only a weak cross-country relationship between deflation and real variables in most years, they also suggest a potentially large indirect role for monetary contraction through a very different channel than those analyzed in the literature. Specifically, there is considerable evidence that falling prices created significant dissatisfaction with prevailing economic and political structures, which in turn fostered the restriction of competition in a number of countries (see Cole and Ohanian (2004) and Ohanian (2009), Tooze (2007), Giordano et al (2012)). Thus, the Depression may have been considerably milder had deflation not been so severe, because cartel policies may not have been expanded in the absence of large deflations in these countries. This suggests that the political economy of cartelization, and the role of deflation in advancing cartel policies and magnifying their impact, are interesting topics for future work. 


\section{References}

[1] Anderson, Evan W., McGrattan Ellen R., Hansen, Lars Peter and Thomas J. Sargent. 1996. Mechanics of forming and estimating dynamic linear economies. Handbook of Computational Economics, in: H. M. Amman, D. A. Kendrick and J. Rust (ed.), Handbook of Computational Economics, edition 1, volume 1, chapter 4, pages 171-252.

[2] Amaral, Pedro S. and James C. MacGee. 2002. The Great Depression in Canada and the United States: A Neoclassical Perspective, Review of Economic Dynamics, 5 (January): $45-72$.

[3] Bernanke, Ben S. 1995. The Macroeconomics of the Great Depression: A Comparative Approach. Journal of Money, Credit, and Banking 27 (February): 1-28.

[4] Bernanke, Ben S., and Kevin Carey. 1996. Nominal Wage Stickiness and Aggregate Supply in the Great Depression. Quarterly Journal of Economics 111 (August): 85383.

[5] Bernanke, Ben S., and Harold James. 1990. The Gold Standard, Deflation, and Financial Crisis in the Great Depression: an International Comparison. Working Paper 3488, National Bureau of Economic Research.

[6] Beaudry, Paul, and Frank Portier. 2002. The French Depression in the 1930s. Review of Economic Dynamics 5 (January): 73-99.

[7] Bridji, Slim. 2012. The French Great Depression: A Business Cycle Accounting Analysis. University of Zurich Department of Economics Working Paper No. 65

[8] Buera, Francisco, Joseph Kaboski, and Yong Shin. 2011. Finance and Development: A Tale of Two Sectors. American Economic Review. 101 (5), pp. 1961-2002.

[9] Bry, Gerard. 1960. Wages in Germany, 1871-1945, Princeton University Press.

[10] Caldara, Dario., Fernandez-Villaverde, Jesus, Rubio-Ramirez, Juan and Wen Yao. 2012. Computing DSGE Models with Recursive Preferences and Stochastic Volatility, Review of Economic Dynamics 15(2): 188-206.

[11] Choudhri, Ehsan U., and Levis A. Kochin. 1980. The Exchange Rate and the International Transmission of Business Cycle Disturbances: Some Evidence from the Great Depression. Journal of Money, Credit, and Banking 12 (November, Part 1): 565-74.

[12] Christiano, Lawrence J., Roberto Motto, and Massimo Rostagno. 2003. The Great Depression and the Friedman-Schwartz Hypothesis. Proceedings, Federal Reserve Bank of Cleveland., pages 1119-1215.

[13] Cole, Harold L. and Lee E. Ohanian. 1999. The Great Depression in the United States from a Neoclassical Perspective. Federal Reserve Bank of Minneapolis Quarterly Review (Winter): 2-24. 
. 2002. The Great U.K. Depression: A Puzzle and Possible Resolution. Review of Economic Dynamics 5 (January): 19-44.

. 2004. New Deal Policies and the Persistence of the Great Depression, Journal of Political Economy, 112(4), 779-816.

[14] Eichengreen, Barry. 1992. Golden Fetters: The Gold Standard and the Great Depression, 1919-1939. NBER Series on Long-Term Factors in Economic Development. Oxford: Oxford University Press.

[15] Eichengreen, Barry, and Jeffrey Sachs. 1985. Exchange Rates and Economic Recovery in the 1930s. Journal of Economic History 45 (December): 925-946.

[16] Fisher, Jonas D. M., and Andreas Hornstein. 2002. The Role of Real Wages, Productivity, and Fiscal Policy in Germany's Great Depression: 1928-1937, Review of Economic Dynamics 5 (January): 100-127.

[17] Giordano, Claire, Gustavo Piga and Giovanni Trovato. 2011. Fascist price and wage policies and Italy's industrial Great Depression, forthcoming Macroeconomic Dynamics.

[18] Kehoe, Timothy J., and Edward C. Prescott. 2002. Great Depressions of the Twentieth Century. Review of Economic Dynamics 5(1): 1-18.

[19] King, Robert G. and Sergio T. Rebelo. 1999. Resuscitating real business cycles, Handbook of Macroeconomics, in: J. B. Taylor \& M. Woodford (ed.), Handbook of Macroeconomics, edition 1, volume 1, chapter 14, pages 927-1007.

[20] James, Harold. 1986. German Slump: Politics and Economics 1924-1936. Oxford: Clarendon Press.

[21] Mendoza, Enrique, 2010. Sudden Stops, Financial Crises, and Leverage. American Economic Review, 100(5), pp 1941-1966.

[22] Ohanian, Lee E. 2003. Liquidity Shocks and the Great Depression: Comment on "The Great Depression and the Friedman-Schwartz Hypothesis" by Lawrence Christiano, Roberto Motto, and Massimo Rostagno, Journal of Money, Credit, and Banking, Vol. 35, No. 6, Part 2: Recent Developments in Monetary Economics (Dec., 2003), pp. 1205-1215.

. 2009. What - or who -started the great depression?, Journal of Economic Theory vol. 144(6): 2310-2335.

. 2010. The Economic Crisis from a Neoclassical Perspective, Journal of Economic Perspectives vol. 24(4): 45-66.

[23] Perri, Fabrizio, and Vincenzo Quadrini. 2002. The Great Depression in Italy: Trade Restrictions and Real Wage Rigidities. Review of Economic Dynamics 5 (January): $128-151$. 
[24] Rose, Jonathan, 2010, "Hoover's Truce: Wage Rigidity in the Onset of the Great Depression, Journal of Economic History, vol. 79(4), 843-870.

[25] Sargent, Thomas J. 1989. Two Models of Measurements and the Investment Accelerator, Journal of Political Economy 97(2): 251-87.

[26] Schedvin, Carl B. 1970. Australia and the Great Depression, Melbourne: Sydney and Oxford University Press.

[27] Shumway, R. H., and D. S. Stoffer. 1982. An approach to time series smoothing and forecasting using the EM algorithm. Journal of Time Series Analysis (3): 253-264.

[28] Tooze, Adam. 2007. The wages of destruction: the making and breaking of the Nazi Economy. New York, NY: Penguin Group.

[29] Zamagni, V. 1994. Una Ricostruzione dell'Andamento Mensile dei Salari Industriali edell'Occupazione 1919-39, in Ricerche per la storia della Banca d'Italia (5): 348-378.

\section{Appendix}

\begin{tabular}{|l|l|l|}
\hline \multicolumn{1}{|c}{ Measurement Error Estimates } \\
\hline & Variable Capacity & Fixed Capacity \\
\hline Output & 0.0006 & 0.0078 \\
\hline Price Level & 0.0051 & 0.0035 \\
\hline Consumption & 0.0044 & 0.0028 \\
\hline Investment & 0.1828 & 0.1349 \\
\hline Labor & $(0.0100)$ & $0.0100)$ \\
\hline TFP & 0.0009 & 0.0027 \\
\hline Money (M1) & 0.0207 & 0.0277 \\
\hline
\end{tabular}

\subsection{Estimation Procedure}

The EM algorithm was used to estimate the model with one modification that was required because of occasional numerical problems in inverting the covariance matrix during some EM iterations. To address this issue, we placed the autoregressive parameters for the money and the labor policy shock and for the standard deviations of the shock innovations on a fine grid, and for each grid point. EM was used to estimate the measurement error variances of the states and the endogenous variables. We then chose the parameter combination with the highest likelihood

\subsection{Equivalent Version with Aggregate Shocks}

The model as it stands now features three shocks, each of which is normally distributed, and which is uncorrelated with the other shocks. The shocks are given by:

$$
\begin{aligned}
V_{t}= & \phi V_{t-1}+\varepsilon_{t} \\
& \varepsilon^{\sim}(0, R)
\end{aligned}
$$


where the matrix $R$ is a diagonal matrix, $V$ is a vector stacking the three shocks, and $\varepsilon$ is a vector stacking the innovations to the shocks.

Next, we consider our model in which the shocks are correlated, which we accomplish by introducing a common shock. Consider the innovation to shock $i, \varepsilon_{i}$. Under the current model, the sample (panel) averages of the mean and variance of $\varepsilon_{i}$ is given by: $\left(\overline{\varepsilon_{i}}, \hat{\sigma}_{i}^{2}\right)$

Next, consider this innovation as the sum of a common component and an idiosyncratic component:

$$
\varepsilon_{i}=c+s_{i}
$$

where $c$ is the common component and $s_{i}$ is the country-specific component. Given that we are working with Gaussian random variables, we have the following restrictions on the means and variances, and the following implication for the mean of $c$. The sum of the means of $c$ and $s_{i}$ is equal to $\overline{\varepsilon_{i}}$, and:

$$
\bar{c}=\overline{\varepsilon_{i}}, \overline{s_{i}}=0, \bar{c}+\overline{s_{i}}=\bar{\varepsilon}_{i}
$$

The sum of the variances of $c$ and $s_{i}$ is equal to $\hat{\sigma}_{i}^{2}: \sigma_{c}^{2}+\sigma_{s}^{2}=\hat{\sigma}_{i}^{2}$

Note that these restrictions imply that the likelihood of the model is unchanged by construction. Specifically, the probability of event $j$ occurring in the model with just a single shock is the same in the world with two shocks. The only difference is that in the second world, the probability of event $j$ occurring is the product of the two events, consisting of the common shock and the country-specific shock.

$\log (L)=-\frac{1}{2} \sum_{t=1} \log \left|M P_{t}^{t-1} M^{\prime}+R\right|-\frac{1}{2} \sum_{t=1}\left(y-M x_{t}^{t-1}\right)^{\prime}\left(M P_{t}^{t-1} M^{\prime}+R\right)^{-1} \sum_{t=1}\left(y-M x_{t}^{t-1}\right)$

where $P_{t}^{t-1}$ is covariance matrix of estimated state conditional on observing $y$ (see equation 7 on page 256 ) and $x_{t}^{t-1}$ is the forecast of the state using t- 1 information.

\subsection{Data}

The primary data source of the data is B.R. Mitchell's International Historical Statistics. This includes most of the data on real and nominal GDP, industrial wages, production and prices, as well as the agricultural and industrial shares of GDP. Data on the stock market and gold parities come from the League of Nations Statistical Yearbooks from 1933 to 1940. Where available, we have used the latest official publications of historical data. This includes the data for Australia, Canada, Japan, the United Kingdom, and the United States. We

have also endeavored to use the latest revisions of data where available. This includes the data for France, Germany, Italy, and Sweden. Listed bellow are the data sources by country. Unless otherwise indicated, the data used are from B.R. Mitchell and the League of Nations.

\section{Australia}

Nominal and real GDP, GDP deflator: Butlin, M.W., 1977, A Preliminary Annual Database 1900/01 to 1973/74, Research Discussion Paper 7701, Reserve Bank of Australia. 
Industrial production, price and wage indices: Australian Historical Statistics (Wray Vamplew, ed.), New York: Cambridge University Press, 1987.

Canada

Nominal and real GDP, GDP deflator, industrial production and wages: Statistics Canada, Historical Statistics (SC-HS).

(http://www.statcan.ca/english/freepub/11-516-XIE/sectiona/toc.htm)

\section{France}

Nominal and real GDP, GDP deflator, industrial production: Beaudry, P., and Portier, F., 2002, The French Depression in the 1930s. Review of Economic Dynamics 5 (January): $73-99$

Note that the data provided by Beaudry and Portier were derived from data in Villa, P., 1993, Une Analyse macro-Economique de la France au XXieme Siecle. Paris: Presses du CNRS.

\section{Germany}

Nominal and real GDP, GDP deflator, industrial wages: Fisher, J., and Hornstein, A., 2002, The Role of Real Wages, Productivity, and Fiscal Policy in Germany's Great Depression, 1928-1937, Review of Economic Dynamics 5 (January): 100-127

\section{Italy}

Nominal and real GDP, GDP deflator, industrial wages, production, and prices: Perri, F., and Quadrini, V., 2002, The Great Depression in Italy: Trade Restrictions and Real Wage Rigidities, Review of Economic Dynamics 5 (January) 128-151.

Note that the data provided by Perri and Quadrini were based on data in (i) Ercolani, P., 1978, Documentazione Statistica di Base in (G. Fua), Lo sviluppo Economico in Italia, 3: 388-472, and (ii) Rey, G., 1991, I Conti Economici dell'Italia, Bari: Laterza.

\section{Japan}

Industrial prices and wages: (i) Hundred-Year Statistics (100 Years) of the Japanese Economy, 1966, Statistics Department, Bank of Japan, and (ii) Supplement to HundredYear Statistics of the Japanese Economy (English translation of footnotes).

\section{Sweden}

Real GDP, GDP deflator, industrial production, prices, and wages: John Hassler's data set at (http://hassler-j.iies.su.se/SWEDATA/).

Note that the data used from Hassler's data set were derived from Krantz, O., and Nilsson, C-A., 1975, Swedish National Product, 1861-1970, Lund.

\section{United Kingdom}

Nominal and real GDP, GDP deflator, industrial production, prices, and wages: Feinstein, C.H., 1972, National Income, Expenditure and Output of the United Kingdom, 1855-1965, Cambridge University Press. 


\section{United States}

Nominal and real GDP, GDP deflator for 1919-29: Romer, C., 1989, The Prewar Business Cycle Reconsidered: New Estimates of Gross National Product, 1869-1908.

Nominal and real GDP, GDP deflator for 1929-40: Bureau of Economic Analysis, National Income and Product Accounts, Table 1.2B and Fixed Asset Tables, Table 1.2.

Industrial production: Board of Governors of the Federal Reserve Bank, series FRB B50001.

Industrial prices: Historical Statistics of the United States: Colonial Times to 1970, part 1, (HSUS), U.S. Bureau of the Census.

Industrial wages: Hanes, C., 1996, Changes in the Cyclical Behavior of Real Wage Rates, 1870-1990, Journal of Economic History. 


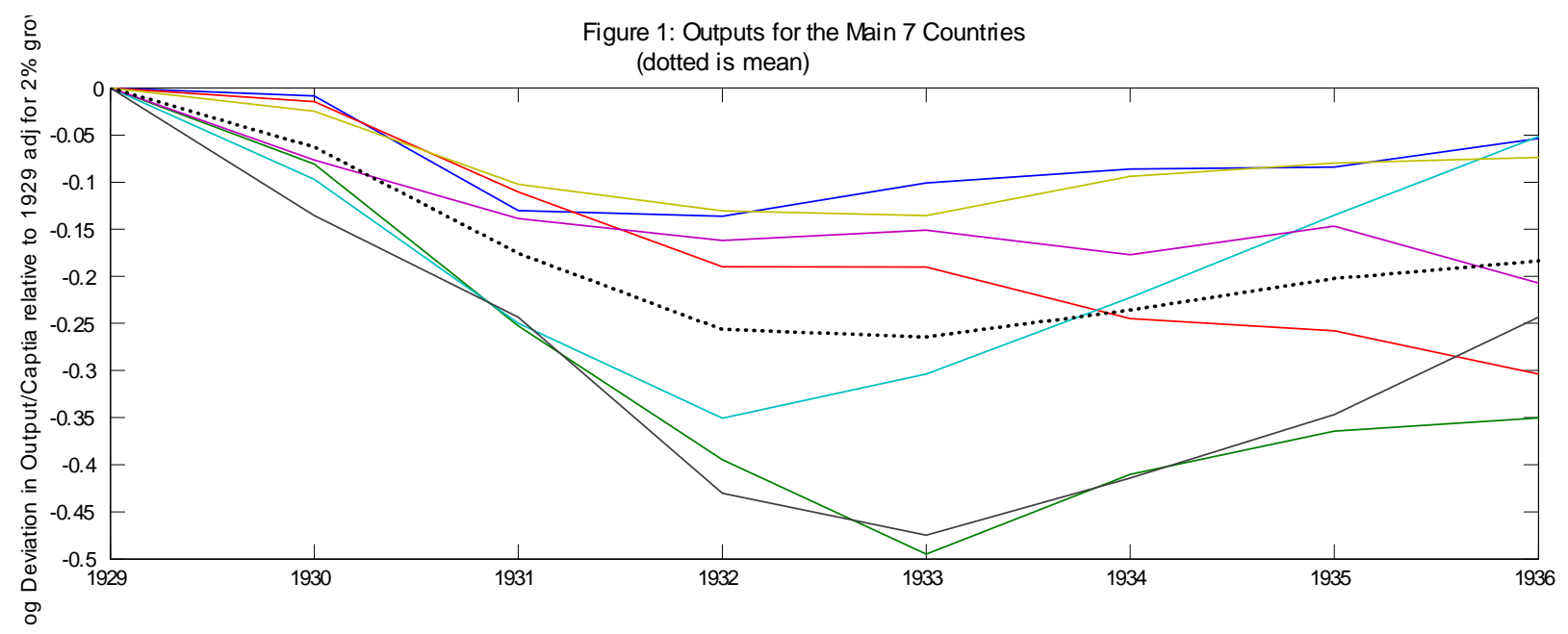

Figure 2: Prices for the Main 7 Countries (dotted is mean)

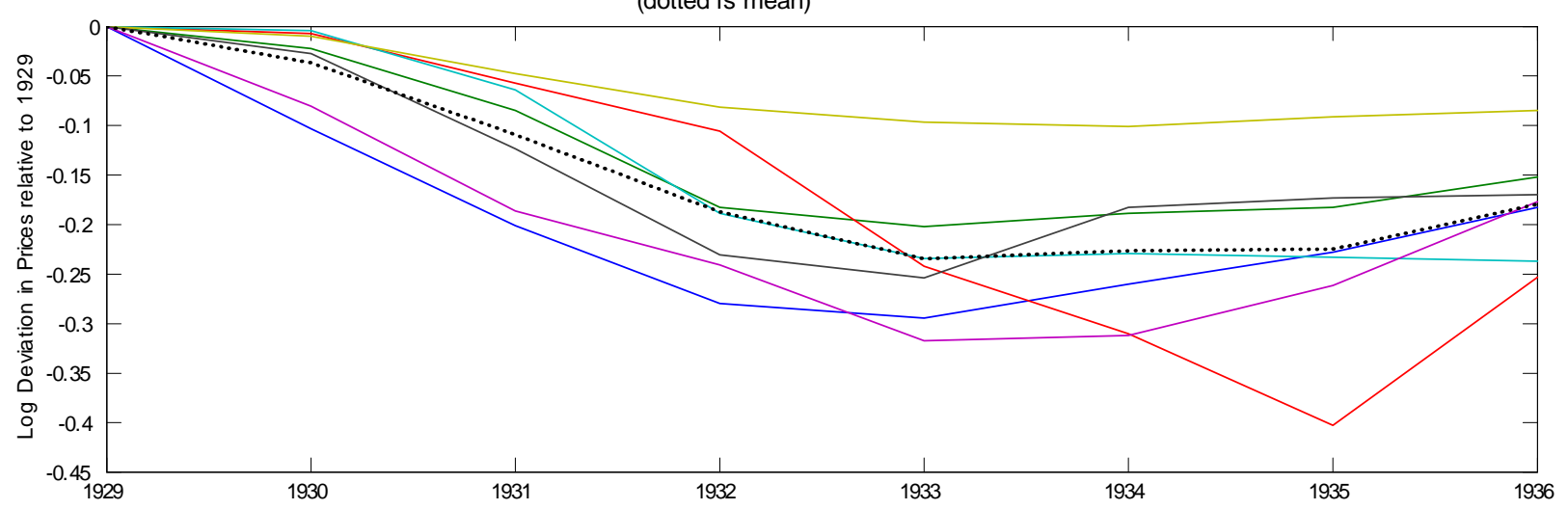

Figure 3: Labor Input for the Main 7 Countries

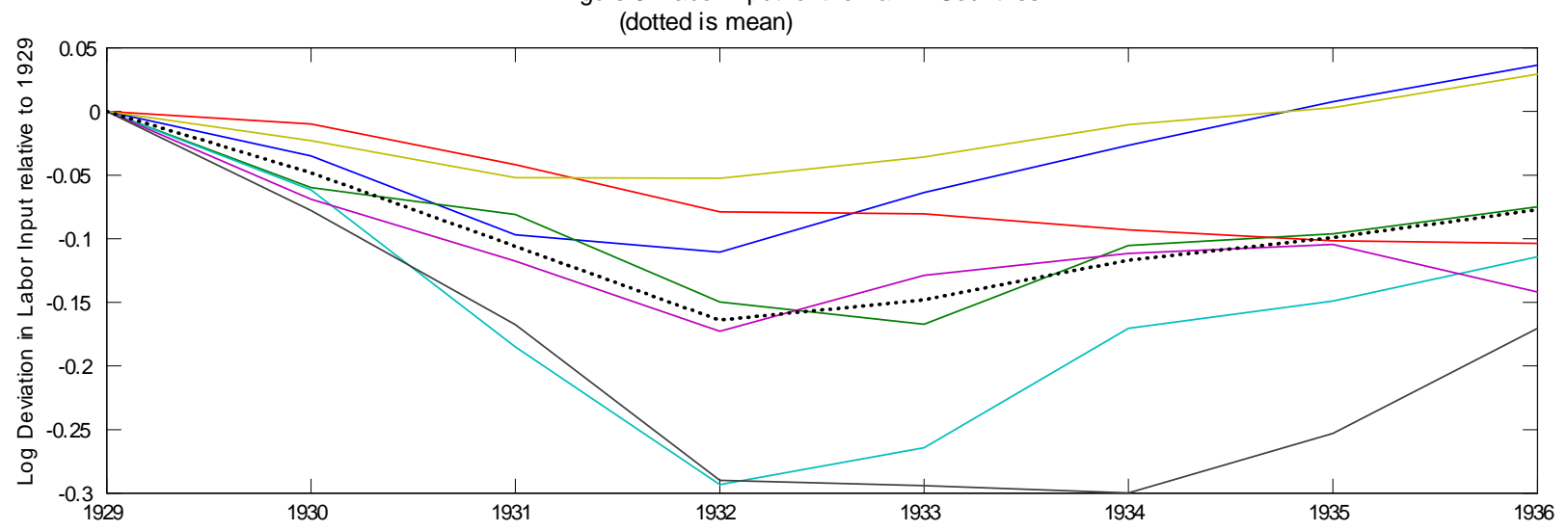


Figure 4: Highest Loglikelihood Conditional on Monetary Nonneutrality
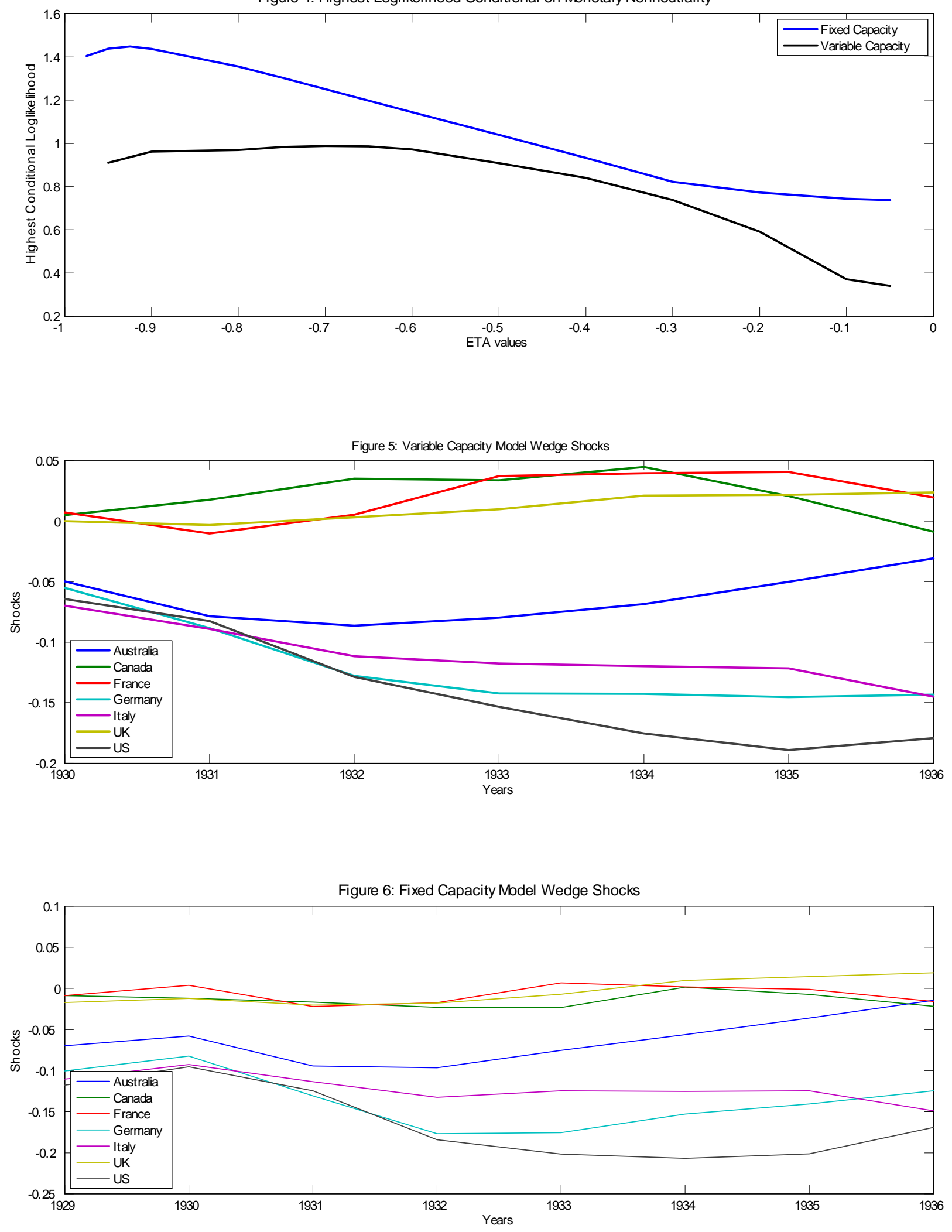


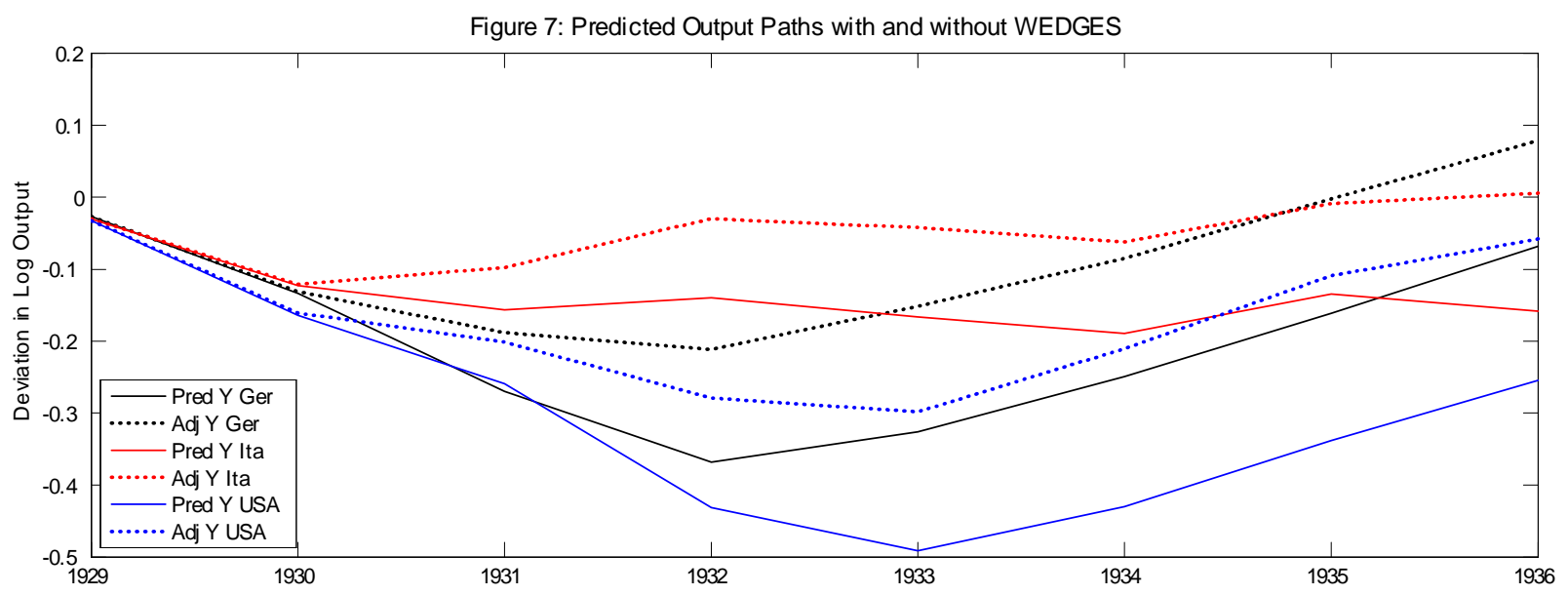

